\title{
Review of the breeding status of birds in Rio Grande do Sul, Brazil
}

\author{
Giovanni N. Maurício ${ }^{1,6}$, Glayson Ariel Bencke ${ }^{2}$, Márcio Repenning ${ }^{3}$, Diogenes Borges Machado 4 \\ Rafael A. Dias ${ }^{5} \&$ Leandro Bugoni ${ }^{1}$
}
1. Laboratório de Aves Aquáticas, Instituto de Ciências Biológicas, Universidade Federal do Rio Grande - FURG, Campus Carreiros, Caixa Postal 474, Av. Itália km 8, 96203-900, Rio Grande, RS, Brazil. (gnachtigallmauricio@yahoo.com.br; lbugoni@yahoo.com.br)
2. Museu de Ciências Naturais, Fundação Zoobotânica do Rio Grande do Sul, Rua Dr. Salvador França 1427, 90690-000, Porto Alegre, RS, Brazil. (gabencke@fzb.rs.gov.br)
3. Programa de Pós-Graduação em Zoologia and Laboratório de Ornitologia, Museu de Ciências e Tecnologia, Pontifícia Universidade Católica do Rio Grande do Sul, Av. Ipiranga 6681, 90619-900, Porto Alegre, RS, Brazil. (mrepenning@gmail.com)
4. Programa de Pós-Graduação em Ecologia, Instituto de Biociências, Universidade Federal do Rio Grande do Sul, Av. Bento Gonçalves 9500, 91501-970, Porto Alegre, RS, Brazil. (diornito@gmail.com)
5. Depto de Ecologia, Zoologia e Genética, Instituto de Biologia, Universidade Federal de Pelotas, Campus Universitária Capão do Leão, Caixa Postal 354, 96010-900, Pelotas, RS, Brazil. (rafael.dias@ufpel.edu.br)

6. Current address: Universidade Federal de Pelotas (UFEPel), Centro de Integração do Mercosul, Rua Andrade Neves, 1529, 96020-080, Pelotas, RS, Brazil.

\begin{abstract}
Information on the breeding biology of birds is essential for improving avian life-history theory and implementing sound management and conservation actions for these organisms. Comprehensive reviews of this kind of information are lacking for most Neotropical regions, including Rio Grande do Sul, the southernmost Brazilian state. Aiming to update the knowledge on the reproductive status of birds in Rio Grande do Sul, we reviewed breeding records of all potential breeding species recorded in the state using a set of predefined, restrictive criteria for accepting breeding evidences as effective. Data satisfying our criteria were available for 165 species in the literature. We also collected novel breeding information obtained in the state for an additional 126 species, including observations for several species whose reproductive biology is poorly known. Among these are birds previously unknown to breed in Brazil. This new data and the critical review of the previous information resulted in a total of 291 species for which breeding evidences are accepted as effective. This corresponds to $54.7 \%$ of the 532 species considered either confirmed or potential breeders in the state. In addition to providing information on nesting dates, clutch size, nest architecture and breeding behavior of south Brazilian birds, our review serves as a benchmark for the adequate assessment of avian breeding records elsewhere. We hope to stimulate observers to rigorously document breeding events, especially for taxa for which basic information is lacking.
\end{abstract}

KEYWORDS. Nest, egg, nestling, breeding biology, breeding records.

\begin{abstract}
RESUMO. Revisão do status reprodutivo de aves no Rio Grande do Sul, Brasil. Informações sobre a biologia reprodutiva das aves são essenciais para aprimorar estudos teóricos sobre a história natural do grupo e implementar ações de manejo e conservação efetivas para esses organismos. Não existem revisões abrangentes sobre o tema para a maioria das regiões neotropicais, incluindo o Rio Grande do Sul, o estado mais meridional do Brasil. Com o objetivo de atualizar o conhecimento sobre o status reprodutivo das aves no Rio Grande do Sul, analisamos os registros reprodutivos de todas as espécies de aves que potencialmente se reproduzem no estado utilizando um conjunto de critérios pré-definidos e restritivos para avaliar a efetividade das evidências reprodutivas. Dados que satisfazem nossos critérios foram encontrados para 165 espécies na literatura. Também compilamos registros de reprodução inéditos obtidos no estado para outras 126 espécies, incluindo observações sobre diversas espécies cuja biologia reprodutiva é pouco conhecida. Entre elas estão espécies cuja reprodução no Brasil era até então desconhecida. Esses novos dados, em conjunto com a revisão crítica dos registros prévios, resultaram em um total de 291 espécies para as quais existem evidências de reprodução efetivas, o que corresponde a 54,7\% das 532 espécies que efetiva ou potencialmente se reproduzem no estado. Além de fornecer informações sobre datas de nidificação, tamanho de postura ou prole, arquitetura de ninhos e comportamento reprodutivo das aves do sul do Brasil, nossa análise serve como referência para a avaliação adequada de registros de reprodução de aves em outras regiões. Esperamos estimular observadores a documentar rigorosamente eventos reprodutivos, especialmente para táxons que carecem de informações básicas.
\end{abstract}

PALAVRAS-CHAVE. Ninho, ovo, ninhego, biologia reprodutiva, registros de reprodução.

Breeding is a key aspect of the life history of any animal species. In birds, studies on reproductive biology vary from simple records of breeding in general avifaunal inventories to detailed studies based on monitoring of nests and young throughout the breeding cycle. Information derived from these studies is essential for the improvement of avian life-history theory and the implementation of sound management and conservation actions for these organisms and their habitats.

In the Neotropics, most studies on breeding biology are descriptive and conducted on a short-term basis, with the notable exceptions of more in-depth investigations on parasitic cowbirds, swallows, threatened parrots, raptors, colonially nesting seabirds and some Passerines (e.g., SNYDER et al., 1987; Moreno et al., 2005; Trejo, 2007; Tuero et al., 2007; MÁrsico \& REBOREDA, 2008; LOMASCOLO et al., 2010; IPPI et al., 2012). In a strong contrast with the North American and European bird faunas, for which basic life history data is available for virtually all species, a large proportion of the South
American avifauna remains poorly known in terms of reproductive biology. Despite intensive field work carried out by several researchers during the last four decades, this scenario is valid even for Rio Grande do Sul, one of the best studied Brazilian states in ornithological terms (Belton, 1984, 1985, 1994; Bencke et al., 2003, 2010).

In this paper we provide a state-of-the-art review on the breeding status of birds in Rio Grande do Sul. We reviewed the literature, included our own observations and applied a set of restrictive criteria for accepting breeding evidences as effective. New observations include data on the breeding activity of over one hundred species for which reproduction has not been previously reported or confirmed in the state. Some of these were unknown to breed in Brazil as well. In addition to updating the comprehensive review undertaken by BeLton (1994), our study provides information that, taken collectively, represents a significant contribution to the current knowledge on the breeding habits of Neotropical birds. 


\section{MATERIAL AND METHODS}

We adopted restrictive criteria for accepting a given breeding record as an effective evidence of reproduction in the state. These criteria were applied only to properly identified species and essentially coincide with the three highest categories of the scale for breeding evidence proposed by BINFORD (1973):

1) Nest with egg(s) observed. This criterion also applies to obligate brood parasites, provided that the parasite's eggs can be diagnosed confidently. However, eggs found unattended out of a nest and suspected to be abandoned or removed by a predator were regarded as insufficient evidence.

2) Nest with young seen or heard. The "young" in this case ranges from a hatchling to an almost full-grown but still flightless individual. The term nestling and its Portuguese equivalent ("ninhego"), commonly used in the literature, were regarded as sufficient to satisfy this criterion even if there was no explicit reference to a nest, based on the assumption that these terms imply a dependent bird necessarily originated from, or found at, a nest. If the young was first seen at a nest but was already fully capable of flight, leaving doubts as to where it was actually born, the record was evaluated under the following criterion, be it of an altricial, semialtricial, semiprecocial or precocial species. We followed STARCK \& RickLEFs (1998) for definition of patterns of development within the altricial-precocial spectrum.

3) Dependent young out of nest. Young birds observed out of a nest and representing any stage of development between a recently hatched and a recently fledged individual having limited (if any) flying ability, thus strongly suggesting that the nest was nearby, is sufficient to satisfy this criterion. Note that precocial and semiprecocial young (sensu STARCK \& Ricklefs, 1998) are included here, even though those of some species are not dependent of adults (e.g., brood parasitic ducks). If flight ability cannot be assessed by direct observation, it must be evaluated by means of indirect evidence. For example, observation of an individual that had still not attained the full growth of its first set of remiges and rectrices was accepted as effective evidence but not the report of a young bird with full grown remiges and rectrices, since the completion of flight feathers' growth renders the young bird fully capable of traveling long distances from the nest site (BINFORD, 1973). If details of the growth stage of flight feathers were not observed or mentioned, a general reference to the small size of the young (e.g., three-quarters sized, half-grown) was accepted as a reliable indication of its inability to perform sustained flights, except for species known to be capable of flying long distances before reaching adult size (e.g., flamingos). Terms widely used in the ornithological literature such as fledgling are not sufficient to satisfy this category if not accompanied by a statement of flying capacity or stage of development of flight feathers. This conservative approach is necessary because the term fledgling, according to BINFORD (1973), is not precise and is restricted by some authors to the stage after completion of juvenal feather growth. The presence of remains of downy feathers alone is also regarded as insufficient to satisfy this category, as fledglings could retain down feathers for several days after leaving the nest (e.g., petrels). Likewise, the sole use of the Portuguese term "filhote", widely employed in the Brazilian ornithological literature, is not sufficient because its application ranges from a nestling to a fullgrown, independent young.

In an initial step, we applied these criteria to the breeding data presented by BELTON (1984, 1985, 1994). We used this source as a baseline for analyzing the available breeding information for the following reasons: i) definition of the breeding status of birds in Rio Grande do Sul (i.e., if a given species is a breeder or a non-breeder within the state) was a central point in this work, with most species having the relevant data presented in an specific account termed "breeding"; ii) this author systematically gathered biological (including breeding) and distributional data on birds throughout the entire Rio Grande do Sul state for more than a decade, and iii) he sought to compile breeding information available in the literature and from several collaborators. At the end of this step, we obtained a comprehensive data set where each species was scored as having either effective or non-effective (if any) evidence of breeding in Rio Grande do Sul.

In a second step, we focused on the search for effective evidence of breeding for species lacking such information, as well as for those added to the state list after BELTON (1994). In this task we used the following sources: i) data published after BeLToN (1994) or overlooked by this author; ii) information from our own field work; iii) observations shared by collaborators, including photographs published at the WikiAves website (http://www.wikiaves.com.br/), whose authors were asked to contribute to the present work; and iv) evidences preserved in regional museum collections.

Because most of the new evidence presented here was obtained opportunistically during fieldwork for other purposes, information provided for each taxon is highly variable with respect to the amount and completeness of data. For several species with poorly known breeding biology a more detailed account is given, including descriptions of nests, eggs, nestlings, or other relevant data. All localities mentioned in the text are followed by the name of the municipality in which it is located. We used the following abbreviations for categories of breeding evidence throughout the text: $\mathrm{NE}$, nest with $\operatorname{egg}(\mathrm{s})$; NY, nest with young; and DY, dependent young with limited mobility and restricted to the natal area. Acronyms of ornithological collections are as follows: MCP, Museu de Ciências e Tecnologia, Pontifícia Universidade Católica do Rio Grande do Sul, 
Porto Alegre, Brazil; MCN, Museu de Ciências Naturais of the Fundação Zoobotânica do Rio Grande do Sul, Porto Alegre, Brazil (oological and nest collections referred to separately by adding the letters "O" and " $\mathrm{N}$ ", respectively). Photographs at the WikiAves website are referred to by their respective catalogue numbers (e.g., WA53374).

\section{RESULTS}

Breeding records published up to BELTON (1994). Only 133 of the 466 bird species (28.5\%; Appendix 1) listed as assumed, confirmed or potential breeders in Rio Grande do Sul by BeLton (1994) qualified as having effective evidence of breeding in the state according to our criteria. Additionally, OliveIRA (1980) reported nests of the Striped Owl Asio clamator containing eggs and young at Porto Alegre, a reference overlooked by BeLton (1984, 1994).

Breeding records published post-BELTON (1994). We found effective breeding evidences for 31 additional species in the literature. These are summarized below.

Coscoroba Swan Coscoroba coscoroba, NE/ NY, wetlands in the southern portion of the state (DiAs \& Fontana, 2002); Yellow-crowned Night Heron Nyctanassa violacea, NE/NY, Ilha da Pólvora, Rio Grande (Gianuca, 2007); Little Blue Heron Egretta caerulea, NE/NY, Ilha dos Marinheiros, Rio Grande (GianuCA et al., 2012); Hook-billed Kite Chondrohierax uncinatus, NY, São Valentim district, Santa Maria (KRÜGEL, 2003); Long-winged Harrier Circus buffoni, NE, Manoel Viana (CAmilotti et al., 2008); Cinereous Harrier Circus cinereus, NE/NY, Pontal da Barra, Pelotas (Bencke et al., 2003); Ornate Hawk-Eagle Spizaetus ornatus, NY, Arroio Taipinha, Esmeralda (JoENCK et al., in press); Collared Forest-Falcon Micrastur semitorquatus, NE/ NY, Presidente Lucena (MARreis et al., 2009); Spotted Rail Pardirallus maculatus, DY following adult, Pontal da Barra, Pelotas (Maurício \& Dias, 1996); Giant Snipe Gallinago undulata, NE, Arroio Água Branca, Bom Jesus (REPENNIng et al., 2010); South-American Painted Snipe Nycticryphes semicollaris, NE, Pontal da Barra, Pelotas (Maurício \& DiAs, 1996); Large-billed Tern Phaetusa simplex, NE/NY, Rio Ibicuí, Manoel Viana (EFE et al., 2001); Black Skimmer Rynchops niger, NE/NY, Rio Ibicuí, Manoel Viana (EFE et al., 2001); Ruddy Quail-Dove Geotrygon montana, NY, Rincão da Caneleira, Pelotas (MAURícIo \& DiAS, 1998); Blue-bellied Parrot Triclaria malachitacea, NY, Monte Alverne, Santa Cruz do Sul (Bencke, 1998); Great Horned Owl Bubo virginianus, NY, Reserva Biológica do Lami, Porto Alegre (Tomazzoni et al., 2004); Silkytailed Nightjar Antrostomus sericocaudatus, DY with adult female, Parque Estadual do Turvo, Derrubadas (BencKe et al., 2003); Great Dusky Swift Cypseloides senex, NE, Cascata do Caracol, Canela (OliveIra, 2011); Red-breasted Toucan Ramphastos dicolorus, NY, Arroio
Andrade, Arroio do Padre (Maurício \& Dias, 1998); Lineated Woodpecker Dryocopus lineatus, NY, Parque Municipal Farroupilha, Pelotas (Maurício \& Dias, 1998); Short-tailed Antthrush Chamaeza campanisona, NE/NY, Sapiranga (Franz, 2013); Bay-capped Wrenspinetail Spartonoica maluroides, NY, Lagoa Pequena, Pelotas (DIAS et al., 2009); Straight-billed Reedhaunter Limnoctites rectirostris, NE/NY, Bom Jesus and São José dos Ausentes (Fontana et al., 2009; RePENNING et al., 2010); Grey-hooded Flycatcher Mionectes rufiventris, NE, Monte Alverne, Santa Cruz do Sul (BencKe, 1995); Brown-breasted Bamboo Tyrant Hemitriccus obsoletus, NE, Monte Alverne, Santa Cruz do Sul (Bencke et al., 2001); Large Elaenia Elaenia spectabilis, NE/NY, Santa Maria (HoffMAnN \& KRÜGEL, 2007); Sharptailed Grass Tyrant Culicivora caudacuta, NY, Arroio Macena headwaters, Vacaria (REPENNING et al., 2010); Black-and-white Monjita Xolmis dominicanus, NE, São Francisco de Paula (Fontana, 1998); Shear-tailed Grey Tyrant Muscipipra vetula, NE, CPCN Pró-Mata, São Francisco de Paula (Fontana et al., 2000); Rustycollared Seedeater Sporophila collaris, NE, Rio Santa Maria floodplain, Dom Pedrito (BENCKE et al., 2003); Black-bellied Seedeater Sporophila melanogaster, NE, several localities in northeastern highlands (ROVEDDER \& FonTANA, 2012).

New records. We obtained new effective evidences of breeding for 126 species. This new data and the critical review of the previous information resulted in a total of 291 species for which breeding evidences are accepted as effective. The novel information is detailed below.

Solitary Tinamou Tinamus solitarius. The species' reproduction was documented at Parque Estadual do Turvo $\left(27^{\circ} 12^{\prime} \mathrm{S}, 53^{\circ} 5^{\prime} \mathrm{W}\right)$, Derrubadas, where a nest with four eggs laid against the base of a tree in deciduous subtropical forest was photographed by E. S. Borsato in October 2003. Additionally, one egg (MCN-O 617) showing weak teeth marks was collected on a trail within primary evergreen forest at the Arroio Ligeiro valley

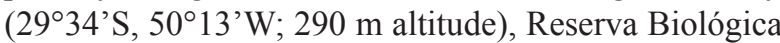
da Serra Geral, Maquiné, 16 December 2004; a second egg was found broken in the same area, also on the trail. It seems likely that both eggs were removed from the same nest by a terrestrial predator (GAB). In January 2007, another egg (MCP 1895) was found lying on the forest floor by a local resident near Aguapés $\left(29^{\circ} 45^{\prime} \mathrm{S}\right.$, $\left.50^{\circ} 13^{\prime} \mathrm{W}\right)$, Osório. Although no adults were seen close to the eggs on any of the above occasions, these were readily identified as being of the Solitary Tinamou on the basis of their size, color and glossed shells.

Brown Tinamou Crypturellus obsoletus. Two eggs incubated by an adult on a depression in the forest floor were photographed at Parque da Ferradura $\left(29^{\circ} 16^{\prime} \mathrm{S}, 50^{\circ} 50^{\prime} \mathrm{W}\right)$, Canela, on 29 December 2006 (A. Osório; WA53374). A nest with four eggs was observed at Cancelão ( $\left.31^{\circ} 22^{\prime} \mathrm{S}, 53^{\circ} 13^{\prime} \mathrm{W}\right)$, Piratini, 17 November 
2012 (DBM).

Small-billed Tinamou Crypturellus parvirostris. Young slightly larger than a chick of domestic chicken but already capable of short flights flew together with adult from dense exotic grass cover at Ijuí (28 $23^{\prime} \mathrm{S}$, 535'ㄱ' 5 June 1999 (GAB).

Tataupa Tinamou Crypturellus tataupa. Adult accompanied by at least two streaked young with the size of a leaftosser Sclerurus sp. seen within primary

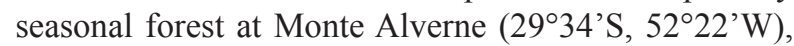
Santa Cruz do Sul, 4 May 1995; on the following day, an almost full-grown juvenile was in the same place: base of bill grayish-pink, upperparts lead-gray (more reddishbrown on back and wings), neck with speckled pattern, remiges barred or spotted, flanks and lower belly scaled dusky (GAB).

Red-winged Tinamou Rhynchotus rufescens. Nests with eggs found at Arroio Água Branca (283'ㅇ, $50^{\circ} 24^{\prime} \mathrm{W}$ ), Bom Jesus, and at CPCN Pró-Mata $\left(29^{\circ} 27^{\prime}-35^{\prime} \mathrm{S}, 50^{\circ} 08^{\prime}-15^{\prime} \mathrm{W}\right)$, São Francisco de Paula, November and December 2008 (MR); one egg collected 30 November (MCP 2425). Also a young incapable of flight photographed at Fazenda Santa Heloísa (31 ${ }^{\circ} 49^{\prime} \mathrm{S}$, $53^{\circ} 36^{\prime} \mathrm{W}$ ), Pedras Altas, February 2006 (RAD; WA696190).

Ringed Teal Callonetta leucophrys. Female followed by a small duckling observed at Granja Quatro Irmãos ( $\left.32^{\circ} 12^{\prime} \mathrm{S}, 52^{\circ} 35^{\prime} \mathrm{W}\right)$, Rio Grande, 5 January 1999 (RAD). This observation was mentioned in DiAS \& BURGER (2005) without explicit reference to the presence of a young.

Red Shoveler Anas platalea. A photograph of a female accompanied by three small ducklings appeared in ENDRIGO (2010). The photograph was taken 24 October 2010 along the Talha-Mar road $\left(31^{\circ} 15^{\prime} \mathrm{S}\right.$, $\left.50^{\circ} 58^{\prime} \mathrm{W}\right)$, Parque Nacional da Lagoa do Peixe, Tavares (E. Endrigo, pers. comm.).

Black-headed Duck Heteronetta atricapilla. Eggs or ducklings of this obligate brood-parasite were found in a total of 32 nests of several waterbird species between October and December 1997 at Banhado do Capão Seco ( $\left.31^{\circ} 49^{\prime} \mathrm{S}, 52^{\circ} 19^{\prime} \mathrm{W}\right)$, Rio Grande (GNM, RAD). Two eggs were collected (MCP 1149, 2944). Eggs of Black-headed Duck were identified according to WELLER (1968) and by accompanying the hatching of a duckling; this and other ducklings found at host nests were identified by the presence of the diagnostic vertical black line from the eye to the crown (WeLLER, 1967). A photograph of one of these ducklings appeared in AzPIRoz (2001) and others are published at the WikiAves website (WA691721, WA693503, WA694147).

Speckled Chachalaca Ortalis guttata. Three breeding records from the Polo Petroquímico de Triunfo $\left(29^{\circ} 52^{\prime} \mathrm{S}, 51^{\circ} 22^{\prime} \mathrm{W}\right)$ : adult incubating three white eggs in nest suspended $3 \mathrm{~m}$ aboveground in tangle of vines at edge of small wood, 6 December 2007; nest about 30 $\mathrm{cm}$ in external diameter and composed of dry leaves and flexible vines; an egg $(60,8 \times 39,8 \mathrm{~mm})$ that fell from the nest overnight and remained suspended in the vegetation was collected on the next day (MCN-O 644; GAB, M. S. Pereira); also downy young with the size of a thrush Turdus sp. and rectrices just emerging from their sheaths accompanying adults 6 December 2006, and family group consisting of two adults and two young one-half the size of their parents, both already capable of weak fluttering flights through the vegetation but still showing the typical pattern of juvenile plumage on head, seen 8 January 2010 (GAB, J. Rosoni). Breeding records elsewhere include two short-tailed young with the size of a Leptotila dove but already able to take flight seen together with adults 11 January 1997 near Santa Cruz do $\mathrm{Sul}\left(29^{\circ} 43^{\prime} \mathrm{S}, 52^{\circ} 26^{\prime} \mathrm{W}\right)$, where another young was with its presumed parents on 19 February 1999 (GAB), and an unhatched egg (MCN-O 738) collected by L. F. S. Carvalho from a nest built just $1 \mathrm{~m}$ from the ground in a hedge at Lami $\left(30^{\circ} 14^{\prime} \mathrm{S}, 51^{\circ} 50^{\prime} \mathrm{W}\right)$, Porto Alegre, October 2010; this nest originally contained two eggs and produced one young. The taxon involved in these records is $O$. g. squamata, an Atlantic forest endemic for which specific status has been proposed recently (REMSEN et al., 2012).

Spot-winged Wood-Quail Odontophorus capueira. A camera trap record of a pair accompanied by two recentlyhatched chicks was obtained at Floresta Nacional de São Francisco de Paula $\left(29^{\circ} 25^{\prime} \mathrm{S}, 50^{\circ} 23^{\prime} \mathrm{W}\right)$ by R. Marques, 22 October 2012.

White-tufted Grebe Rollandia rolland. Floating nests with two and three eggs attended by adults, and small young following an adult, seen and photographed in October 1997 at Banhado do Capão Seco, Rio Grande (GNM, RAD; WA696193). Egg collected November 1997 at the same place (MCP 2931).

Neotropic Cormorant Phalacrocorax brasilianus. Two eggs (MCN-O 446, 447) were collected by F. Silva in a mixed nesting colony at Banhado do Capivari $\left(30^{\circ} 11^{\prime} \mathrm{S}, 50^{\circ} 34^{\prime} \mathrm{W}\right)$, Capivari do Sul, November 1980 (see Belton, 1994; Silva \& Fallavena, 1995). Additionally, a monospecific colony with 80 nests was mentioned in BARQUETE et al. (2008) on the basis of observations of A. S. Peter in Mostardas (30 $57^{\prime} \mathrm{S}$, 5053'W), 26 June 2005.

Anhinga Anhinga anhinga. At least four nests, one of which containing two large flightless chicks, were observed in a mixed-species heronry in an impoundment $\left(31^{\circ} 23^{\prime} \mathrm{S}, 53^{\circ} 45^{\prime} \mathrm{W}\right)$ at Candiota, 19 January 2007 (RAD). Another large flightless chick was photographed in a mixed colony with egrets and spoonbills at Reserva Biológica do Mato Grande ( $\left.32^{\circ} 08^{\prime} \mathrm{S}, 52^{\circ} 38^{\prime} \mathrm{W}\right)$, Arroio Grande, by C. N. Barreto, 20 January 1984.

Rufescent Tiger-heron Tigrisoma lineatum. Unlined nest of sticks built about $1 \mathrm{~m}$ above water on leafless maricá tree Mimosa bimucronata (Fabaceae) in sparse woody vegetation on flooded margin of artificial lake at the Polo Petroquímico de Triunfo, with adult 
seen nearby, 8 January 2010 . One white egg, very lightly speckled and scribbled with scattered gray-brown and vinaceous markings (GAB, J. Rosoni).

Pinnated Bittern Botaurus pinnatus. Nest with a single pale-gray, downy nestling (photographed) found in a rice field at Granja Quatro Irmãos, Rio Grande, 7 February 2002 (RAD, C. P. Calabuig, M. D. M. Burns); adult seen nearby.

Green Ibis Mesembrinibis cayennensis. Pair of adults feeding much smaller young with remains of down plumage at Capela do Caravaggio $\left(28^{\circ} 08^{\prime} \mathrm{S}\right.$, $50^{\circ} 54^{\prime} \mathrm{W}$ ), Vacaria, December 2008 (MR).

Plumbeous Ibis Theristicus caerulescens. A pair attending a nest built in an unidentified sarandi bush in small impoundment and containing a small downy chick was observed 2 December 2007 at Fazenda São Francisco (31 $\left.{ }^{\circ} 54^{\prime} \mathrm{S}, 53^{\circ} 37^{\prime} \mathrm{W}\right)$, Pedras Altas (RAD, V. A. G. Bastazini).

Turkey Vulture Cathartes aura. Nestlings with remains of down sitting in scrapes on ground among large boulders were photographed November 2006 at $32^{\circ} 04^{\prime} \mathrm{S}, 53^{\circ} 31^{\prime} \mathrm{W}$ near Herval (GAB) and January 2001 at Fazenda Santa Rosa $\left(32^{\circ} 06^{\prime} \mathrm{S}, 53^{\circ} 07^{\prime} \mathrm{W}\right)$, Arroio Grande (RAD; WA691060). Adult with nest containing one egg observed September 2005 at Cerrito $\left(31^{\circ} 22^{\prime} \mathrm{S}\right.$, $\left.51^{\circ} 22^{\prime} \mathrm{W}\right)$, Arroio do Padre (GNM).

Black Vulture Coragyps atratus. Two large downy young observed at nest on ground at base of Erythrina tree (Fabaceae) in sawgrass Scirpus giganteus (Cyperaceae) marsh at Pontal da Barra (31 $\left.{ }^{\circ} 47^{\prime} \mathrm{S}, 52^{\circ} 14^{\prime} \mathrm{W}\right)$, Pelotas, were photographed in December 1994 (GNM, RAD; WA692696). Breeds regularly within the urban area of Porto Alegre $\left(30^{\circ} 04^{\prime} \mathrm{S}, 51^{\circ} 11^{\prime} \mathrm{W}\right)$, where a partially feathered young was successfully translocated from its nest, located in flower box of apartment, to the cover of the same residential building, 28 December 2011 (GAB, S. Ribeiro).

Savanna Hawk Heterospizias meridionalis. Large non-volant nestling photographed at a nest $5 \mathrm{~m}$ up on Eucalyptus tree at Taim $\left(32^{\circ} 30^{\prime} \mathrm{S}, 52^{\circ} 35^{\prime} \mathrm{W}\right)$, Rio Grande, 28 December 2004 (RAD; WA693505). An adult was observed nearby.

White-tailed Hawk Geranoaetus albicaudatus. Nest with one young at Cabanha da Divisa (28 $54^{\prime}$ 'S, 533'' 'W), Cruz Alta, 10 November 2012 (DBM).

Southern Caracara Caracara plancus. Nest with two chicks a few weeks old but still flightless observed in transmission tower at Banhado do Capão Seco, Rio Grande, October and November 1999 (RAD). Another nest with young observed at Parque Nacional da Lagoa do Peixe ( $\left.31^{\circ} 18^{\prime} \mathrm{S}, 51^{\circ} 00^{\prime} \mathrm{W}\right)$, Tavares, November 2003 (MR).

Chimango Caracara Milvago chimango. A nest on the ground containing one egg photographed in salt marsh at the mouth of the Lagoa do Peixe $\left(31^{\circ} 21^{\prime} \mathrm{S}\right.$, $51^{\circ} 02^{\prime} \mathrm{W}$ ), Tavares, October 2006 (RAD, GAB; WA694142).

American Kestrel Falco sparverius. Five nestlings covered with white down were successfully translocated from a nest built in air-conditioning hole on the eighth floor of residential building in Porto Alegre to the cover of the same building in November 2007 (GAB, S. Ribeiro).

Gray-necked Wood-Rail Aramides cajanea. Adults accompanied by three dull-plumaged young with three-quarters adult size observed west of São Francisco de Assis in the riparian woodland of the Rio Inhacundá $\left(29^{\circ} 31^{\prime} \mathrm{S}, 55^{\circ} 10^{\prime} \mathrm{W}\right), 12$ January 2011 (GAB, RAD).

Giant Wood-Rail Aramides ypecaha. Pair of adults followed by two short billed, two-thirdsized young at Banhado do Vinte-e-cinco ( $31^{\circ} 59^{\prime} \mathrm{S}$, $52^{\circ} 17^{\prime} \mathrm{W}$ ), Rio Grande, 2 January 1999 (GNM). Also a nest with five eggs in tall grass clump at edge of canal

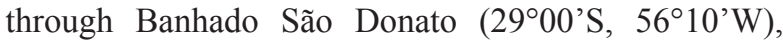
with adult incubating 20 November 2002 (GAB). Another nest, with three eggs, discovered 5 March 2010 within a clump of Eryngium sp. (Apiaceae), sedges and grasses on edge of grassy marsh southwest of Sentinela do Sul (30²' 'S, $51^{\circ} 39^{\prime} \mathrm{W}$; M. Pairet, GAB). A small downy chick was photographed in the Rio Santa Maria floodplain (30 $\left.56^{\prime} \mathrm{S}, 54^{\circ} 43^{\prime} \mathrm{W}\right)$ near Dom Pedrito, 21 January 2009 (RAD, GAB; WA691059).

Red-and-white Crake Laterallus leucopyrrhus. Spherical nest with circular lateral entrance in sawgrass clump near ground built of dead sawgrass leaves and containing at least three creamy-white eggs with what appeared to be small brown stain marks was seen at Vila Fortaleza (untraced), Triunfo, 7 October 2009 (C. N. Kuhn). Both the nest and the adult bird attending it were photographed (WA66046, WA66232).

Rufous-sided Crake Laterallus melanophaius. Family group with two adults and four young at different stages of development observed in flooded grassland along ditch at edge of rice paddy in the floodplain of the Arroio Taquari-Mirim $\left(29^{\circ} 40^{\prime} \mathrm{S}, 52^{\circ} 18^{\prime} \mathrm{W}\right)$, Santa Cruz do Sul, 12 January 1997. Older young similar to adults but duller and with forehead and sides of crown black; younger chicks dark above with contrasting white patch on cheeks, throat whitish coarsely streaked black, sides of breast extensively rufous, underparts whitish with a narrow black stripe running down from the center of the throat and becoming wider on the chest, lower flanks blotched with black, undertail coverts rufous, tarsi and feet light olive-yellow, and bill horn-colored. Intermediate young with throat white, lower flanks barred black and no black stripe on chest. Adults tape-recorded (GAB). Two few days-old blackish chicks accompaying adults observed crossing floating vegetation of irrigation canal on 28 November 2010 at Banhado São Donato ( $\left.29^{\circ} 01^{\prime} \mathrm{S}, 56^{\circ} 10^{\prime} \mathrm{W}\right)$, Maçambará (MR).

Plumbeous Rail Pardirallus sanguinolentus. A photograph of an adult brooding 3-4 downy chicks appeared in ENDRIGO (2010); the photograph was taken in a small marshy creek near Mostardas at $31^{\circ} 04^{\prime} \mathrm{S}$, $50^{\circ} 5^{\prime} \mathrm{W}$ (E. Endrigo, pers. comm.). At Pontal da Barra, 
Pelotas, single adults accompanied by two downy chicks and two well-grown young were observed December 1997 and January 1998, respectively (GNM). In addition, downy chicks accompanied by single adult were observed near Candiota ( $\left.31^{\circ} 30^{\prime} \mathrm{S}, 53^{\circ} 41^{\prime} \mathrm{W}\right), 10$ November 1999 (GAB).

Red-fronted Coot Fulica rufifrons. Nests with eggs built in bulrush stands in grassy marsh and small downy chicks following adults seen at Banhado do Capão Seco, Rio Grande, October and November 1997 (GNM, RAD). Chicks photographed.

South American Snipe Gallinago paraguaiae. Nest with two conical eggs hidden in grass tussock discovered in waterlogged field close to extensive marshland at Dom Pedrito (30 $55^{\prime}$ 'S, 54 $\left.41^{\prime} \mathrm{W}\right), 9$ February 1998, with adult incubating (GAB). Another nest with three eggs found at Quaraí (30²8'S, 56 $21^{\circ}$ 'W) in June 2007 (MR), and small chick seen at EMBRAPA Clima Temperado (31 $\left.{ }^{\circ} 49^{\prime} \mathrm{S}, 5^{\circ} 26^{\prime} \mathrm{W}\right)$, Capão do Leão, 27 September 1999 (GNM). Also a short-billed juvenile with remains of down on head and only capable of short flights caught by hand and photographed at Estância São Crispim (3041'S, 5357'W), Lavras do Sul, 7 August 2007 (RAD, GAB, P. Develey).

Brown-hooded Gull Chroicocephalus maculipennis. MAurício \& DiAs (1996) reported breeding at Banhado do Capão Seco, Rio Grande, November 1995, without details. Large colonies, some containing over 100 nests, were recorded on that and other occasions during the spring of that and subsequent years (RAD, GNM). Nests containing eggs and small chicks were photographed November and December 1997 (WA691711, WA691717, WA691718). Three eggs from different nests were collected 19 and 24 November 1997 (MCP 2934, 2936, 3459).

Grey-headed Gull Chroicocephalus cirrocephalus. The species was seen breeding (nests with eggs) in a small monospecific colony at Barragem Sanchuri (29³4'S, 5648'W), Itaqui, 21 November 1998 (LB, S. B. Scherer, M. A. Efe). Two pairs were nesting at Banhado do Capão Seco, Rio Grande, November 1995, in a mixed-colony with the Brown-hooded Gull and the Snowy-crowned Tern Sterna trudeaui (MAURícIO \& Dias, 1996). The species has been observed breeding regularly since then in the latter locality during the spring, and appears to be increasing in numbers (RAD). An egg was collected from a nest containing three eggs, 12 December 2000 (MCP 3458).

Gull-billed Tern Gelochelidon nilotica. The remains of a predated egg (MCN-O 740) were collected on 23 October 2011 from a nest discovered with three eggs on 18 October in coastal dunes between Tramandaí and Cidreira at $30^{\circ} 06^{\prime} \mathrm{S}, 50^{\circ} 11^{\prime} \mathrm{W}$ (J. Sanabria).

Snowy-crowned Tern Sterna trudeaui. MAurício \& DiAs (1996) reported breeding at Capão Seco, Rio Grande, November 1995, without details. Breeds regularly in mixed colonies with Brown-hooded and
Grey-headed Gulls at Banhado do Capão Seco, Rio Grande, during spring (RAD). Nests containing eggs and small chicks were photographed (WA697297, WA697299, WA697300) and one egg was collected (MCP 2935) from a nest containing three eggs, 19 November 1997, at the same locality (RAD).

Rock Dove Columba livia. Nests in buildings in cities and towns throughout the state. Nest with two nestlings attended by free-living birds observed at Campus Carreiros da Universidade Federal do Rio Grande (32 $\left.{ }^{\circ} 04^{\prime} \mathrm{S}, 52^{\circ} 10^{\prime} \mathrm{W}\right)$, Rio Grande, 16-17 August 2012 (GNM). Adult incubating two eggs photographed at the same locality by A. Borowski, 9 October 2012 (WA771379). Several nests with eggs and flightless chicks observed all months from March 2009 to May 2010 on building of the Porto Novo, Rio Grande $\left(32^{\circ} 02^{\prime} \mathrm{S}, 52^{\circ} 04^{\prime} \mathrm{W}\right)$, Rio Grande (LB, A. C. F. GomesJr.).

Gray-fronted Dove Leptotila rufaxilla. At the Polo Petroquímico de Triunfo, a bird positively identified by plumage was incubating in nest built $3.75 \mathrm{~m}$ up over tangle of horizontal branches and lianas in small tree overhanging a trail at edge of secondary forest, 25 October 2012 (GAB, A. M. Lima, M. S. Pereira, C. M. da Glória). Nest collected (MCN-N 100).

Monk Parakeet Myiopsitta monachus. A fullyfeathered but still non-volant nestling was photographed atop a fallen nest at Fazenda Nossa Senhora de Guadalupe (31 ${ }^{\circ} 47^{\prime}$ S, 52³9’W), Capão do Leão, 17 December 2006 (RAD, M. S. S. Gonçalves; WA694143).

Tropical Screech-Owl Megascops choliba. A fluffy young with barred mesoptile plumage, no sign of ear tufts and age estimated at 30-40 days according to the development sequence illustrated in OLIVEIRA (1984) was photographed at the Jardim Botânico de Porto Alegre (3003'S, 51 $\left.10^{\prime} \mathrm{W}\right), 29$ October 2004. Although adults were not located to confirm identification, $M$. choliba is the only species of the genus recorded in over ten years of observations in the area.

Burrowing Owl Athene cunicularia. The nesting burrows of this species are commonly found in open areas throughout most of the state. Young birds at nest entrance, either alone or accompanied by adults, were seen at Encruzilhada do Sul (30³4'S, 52 $\left.36^{\prime} \mathrm{W}\right), 20$ December 1996 (GAB); Rosário do Sul (30¹9'S, $\left.55^{\circ} 11^{\prime} \mathrm{W}\right), 20$ January 2010 (GAB, RAD); and near the mouth of the Lagoa dos Patos (32 $\left.{ }^{\circ} 09^{\prime} \mathrm{S}, 52^{\circ} 06^{\prime} \mathrm{W}\right), 24$ October 2011 (LB).

Common Potoo Nyctibius griseus. A one-third sized young mostly in downy plumage attended by adult in the urban area of São Leopoldo (2946'S, $\left.51^{\circ} 09^{\prime} \mathrm{W}\right)$ was photographed on 27 January 2010 (C. Schwertner; WA104187).

Rufous Nightjar Antrostomus rufus. Adult incubating two eggs within Eucalyptus plantation with understory of scattered native shrubs at Mariana Pimentel (30¹9’S, 51³2’W), 24 October 1997. Eggs 
white with gray to reddish-brown speckles, laid in simple depression on leaf-littered ground, with no lining (GAB, A. Kindel).

Pauraque Hydropsalis albicollis. Two young less than one-fourth full size photographed with adult at Lomba Grande (29 43 'S , 51 $\left.{ }^{\circ} 04^{\prime} \mathrm{W}\right)$, Novo Hamburgo, 13 November 2012 (A. Bomm; WA533485, WA533483).

Band-winged Nightjar Hydropsalis longirostris. A nest with two eggs laid directly on bare rock in grassland area was photographed $2 \mathrm{~km}$ west of Bom Jesus (28 $\left.40^{\circ} \mathrm{S}, 50^{\circ} 26^{\prime} \mathrm{W}\right), 10$ January 2010 (MR). In addition, a young about half the size of adults and with poor flight ability was captured in a residential area of Porto Alegre and brought to GAB on 28 November 2004; the bird died after 36 days in captivity and was preserved (MCN 2736).

Sooty Swift Cypseloides fumigatus. Three nests were found along a short section of the Arroio Jacob (main fork of the Arroio Feitoria) near Picada Verão (293' S, 51 $\left.{ }^{\circ} 01^{\prime} \mathrm{W}\right)$, Sapiranga, in October/November 1989. The first nest was a flat platform resting about $4 \mathrm{~m}$ high on small ledge of vertical wall in large sandstone cave behind the main waterfall of Arroio Jacob. It contained an incubating bird on 28 October and possibly a chick on 5 November. The second nest was found upstream inside a small crevice on the rocky bank of the stream, with one white egg $(29.8 \times 19.3$ $\mathrm{mm}$ ) incubated by an adult on 5 November; the newly hatched chick, completely naked and weighing $7 \mathrm{~g}$, was ringed on 18 November and remained in the nest on 19 December, when almost fully feathered and weighing $45.5 \mathrm{~g}$, but with semiplumes (which form the down-like nestling plumage of Cypseloides, see Collins, 1963) still showing up amidst growing contour feathers on belly and flanks, and with remiges, forewing, undertail coverts, and feathers of forehead, back, rump, lower breast and abdomen narrowly to thinly margined white. The third nest, similar in shape to the first one, contained one egg $(28.6 \times 18.7 \mathrm{~mm})$ on 5 November and was placed just above the water behind overhang of the rocky bank of the stream. Site of the first nest was reused in November 1990, when a fourth nest, also containing a single white egg $(30.5 \times 19.5 \mathrm{~mm})$, was located in the same cave (GAB). Materials used for nest construction included mud, three types of mosses (one possibly Fissidentaceae) and small ferns of the genus Selaginella (Selaginellaceae). Nests contained much less mud and much more vegetable matter than those depicted in Biancalana et al. (2012). In Nest 2 mud was used mainly to form the base of the cup-shaped structure. Nests varied in shape according to the characteristics of the substrate, as found by others elsewhere (MARÍN \& Stiles, 1992; VASCONCelos et al., 2006). Singleegg clutches have now been documented from widely scattered localities across the known geographic range of the Sooty Swift and seem to be the rule for this species (Chantler, 2000; Vasconcelos et al., 2006; Pearman et al., 2010; Biancalana et al., 2012).

White-collared Swift Streptoprocne zonaris. Two nests discovered in October 1989 together with the nests of C. fumigatus above, both attached to vertical walls of the large sandstone cave behind the Arroio Jacob's main waterfall. The first was a shallow platform built $5 \mathrm{~m}$ high on the flat base of a small hole in the rock, with adult incubating on 28 October. The second was a high cup attached to the bottom corner of a vertical rocky crevice about $3.5 \mathrm{~m}$ aboveground, consisting of a soft mass of ferns Selaginella (Selaginellaceae), mosses, liverworts (genus Dumortiera) and a viscous substance that could be saliva of the bird; this nest measured $16 \mathrm{~cm}$ in height and had internal diameter and internal depth of $91 \mathrm{~mm}$ and $37.5 \mathrm{~mm}$, respectively; it contained two elongated, light clay-color eggs ( $38.2 \times 24.7$ and $32.6 \times 24.4 \mathrm{~mm})$ on 29 October. In both nests, incubation was still in progress on 4 November. A feathered young (weight $154.5 \mathrm{~g}$ ) with neck collar complete but appreciably narrower and less defined than in adults was ringed at the second nest on 19 December. The site of this nest was reused in $1990(\mathrm{GAB})$.

Grey-rumped Swift Chaetura cinereiventris. Typical Chaetura nest found attached $3 \mathrm{~m}$ up inside hollow canjerana tree Cabralea canjerana (Meliaceae) with diameter at breast height of $\pm 80 \mathrm{~cm}$ in primary mid-elevation forest (450 $\mathrm{m}$ altitude) at Reserva Biológica da Serra Geral $\left(29^{\circ} 34^{\prime}-38^{\prime} \mathrm{S}, 50^{\circ} 11^{\prime}-12^{\prime} \mathrm{W}\right)$, Maquiné, 14 March 2006. Adults - not seen on the occasion, but recorded in the area - possibly entered tree hollow through a small upward-facing hole $c .2 \mathrm{~m}$ above the nest. Specific identification based on the voice of the young (not seen), clearly different from that of $C$. meridionalis (GAB, pers. obs.), since these are the only species of the genus present in Rio Grande do Sul (GAB, J. K. Mähler Jr.).

Scale-throated Hermit Phaethornis eurynome. Nest with nestlings attended by adult at Parque Estadual do Turvo, Derrubadas, 19 November 2009 (D. Meller). Brooding adult photographed at nest (WA85989).

Violet-capped Woodnymph Thalurania glaucopis. Two nests with nestlings, one of which containing newly hatched young, were found 1.0 and $1.8 \mathrm{~m}$ above ground within primary seasonal forest at Monte Alverne, Santa Cruz do Sul, between 6-9 October 1995. A female was incubating two eggs on 14 December 2004 in a nest attached $0.7 \mathrm{~m}$ up to stems of a small bamboo Chusquea sp. (Poaceae) within primary evergreen forest on the lower slopes of the Arroio Encantado valley (29 $36^{\prime}$ S, $\left.50^{\circ} 11^{\prime} \mathrm{W} ; 310 \mathrm{~m}\right)$, Reserva Biológica da Serra Geral, Maquiné. Another nest, containing two newly-hatched young and eggshell remains, was built $0.6 \mathrm{~m}$ from ground in lowland evergreen forest around the Lagoa do Jacaré $\left(29^{\circ} 19^{\prime} \mathrm{S}, 49^{\circ} 51^{\prime} \mathrm{W}\right)$, Torres (GAB).

White-tailed Goldenthroat Polytmus guainumbi. Nest with two eggs incubated by female photographed on 25 December 2012 at edge of marsh $3 \mathrm{~km}$ south 


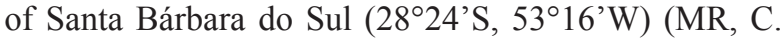
Beier; WA942007).

Glittering-throated Emerald Amazilia fimbriata. A newly-fledged young fed by a presumed female was photographed on 3 October 2008 in garden within urban area of Dom Pedro de Alcântara (29 $\left.22^{\prime} \mathrm{S}, 49^{\circ} 51^{\prime} \mathrm{W}\right)$; the empty nest was $2.5 \mathrm{~m}$ aboveground on the same bushy tree where the young was located. The nest was a compact, moderately high cup saddled on horizontal branch $1 \mathrm{~cm}$ in diameter, made of a pale rusty vegetable wool and entirely covered on outside with fragments of a whitish foliose lichen (genus Parmotrema, Parmeliaceae). The taxon involved is $A$. $f$. tephrocephala, endemic to the coastal restingas of southeastern Brazil, from Espírito Santo to Rio Grande do Sul

Blue-tufted Starthroat Heliomaster furcifer. At Parque Estadual do Espinilho (30 $11^{\circ}$ 'S, 57 $7^{\circ} 30^{\prime} \mathrm{W}$ ), Barra do Quaraí, nests with two eggs were monitored during January 2013 (C. Beier, pers. comm.). Additionally, examination of the juvenal specimen (MCN 883) cited by BELTON (1984), collected in the western tip of the state along with the adult female MCN 882 in November 1977, clearly revealed that it is a newly-fledged young, as indicated by its short bill, wings and tail, the latter barely reaching half the length of that of the adult female.

White-eared Puffbird, Nystalus chacuru. Two recently fledged young barely capable of flight were observed on 22 December 2005 at Coxilha Grande $\left(28^{\circ} 17^{\prime}\right.$ S, $50^{\circ} 54^{\prime} \mathrm{W}$ ), Vacaria (MR, C. E. Rovedder, C. S. Fontana), one of which was hand-caught and photographed.

Toco Toucan Ramphastos toco. At least one nestling was observed in top cavity in dead jerivá palm Arecastrum romanzoffianum (Arecaceae) in marshy swale at Alto Alegre ( $\left.31^{\circ} 43^{\prime} \mathrm{S}, 52^{\circ} 52^{\prime} \mathrm{W}\right)$, Cerrito. This nest, attended by two adults, was briefly studied between 19 December 2003 and 9 January 2004 (C. B. Andretti, M. S. S. Gonçalves, RAD). Another nest with four eggs was found near Fazenda Cerro Alegre $\left(31^{\circ} 22^{\prime} \mathrm{S}\right.$, $\left.53^{\circ} 17^{\prime} \mathrm{W}\right)$, Piratini, 16 November 2012 (DBM).

Ochre-collared Piculet Picumnus temminckii. Nestlings were calling inside a nest hole at edge of a semideciduous forest fragment at Campo Bom (29 $37^{\prime} \mathrm{S}$, $\left.51^{\circ} 02^{\prime} \mathrm{W}\right), 26$ November 2011 . The nest was $\sim 2.5$ $\mathrm{m}$ aboveground in a dead tree partially covered with lianas. Both adults delivered food to nestlings every 1-3 minutes (I. Franz).

Mottled Piculet Picumnus nebulosus. A photograph of a male feeding a nestling at the entrance of a tree hole appeared in ENDRIGO (2010). The photograph was taken on 17 December 2009 at Hotel Veraneio Hampel (292'소 $\left.50^{\circ} 36^{\prime} \mathrm{W}\right)$, São Francisco de Paula (E. Endrigo, pers. comm.).

White-spotted Woodpecker Veniliornis spilogaster. Nestlings fed at entrance of nest cavity in a dead Myrsine sp. (Myrsinaceae) tree at FEPAGRO $\left(30^{\circ} 04^{\prime} \mathrm{S}\right.$, $51^{\circ} 18^{\prime} \mathrm{W}$ ), Eldorado do Sul, December 2005 (MR).

Green-barred Woodpecker Colaptes melanochloros.
Young in nest cavities excavated in trees seen at Parque Eólico de Osório (2957'S, 50¹6’W), Osório; Sans Souci $\left(30^{\circ} 01^{\prime} \mathrm{S}, 51^{\circ} 18^{\prime} \mathrm{W}\right)$, Eldorado do Sul; and Areal $\left(30^{\circ} 26^{\prime} \mathrm{S}, 5^{\circ} 23^{\prime} \mathrm{W}\right)$, Quaraí (MR). All records OctoberFebruary.

Robust Woodpecker Campephilus robustus. A pair fed young at entrance of nest in tree cavity at Alpes de São Francisco (29²6’S, 50³6’W), São Francisco de Paula, September 2006 (MR).

Plain Antvireo Dysithamnus mentalis. Nest with two eggs in seasonal broadleaf forest at Monte Alverne, Santa Cruz do Sul, with female seen incubating the evening of 28 October 1995 and male on the morning of the next two days; nest empty on 11 November. Eggs whitish, one with purple blotches scattered across the surface and the other almost immaculate, but with a broad purple crown on the largest end (GAB).

Squamate Antbird Myrmeciza squamosa. Female followed by a fledgling with fleshy, pale yellow rictus on ground and lower strata of secondary coastal forest at Reserva Biológica da Mata Paludosa (2930'S, $\left.50^{\circ} 06^{\prime} \mathrm{W}\right)$, Itati, 2 December 1995 (GAB, A. Kindel). Young dark overall, with crown and back brown, forehead, ear coverts and underparts blackish, and a white patch on center of breast.

Rufous Gnateater Conopophaga lineata. Three nests containing one, two and two eggs were found, respectively, in Santa Cruz do Sul on 29 December 1992 (GAB), Santo Amaro (29 $\left.56^{\prime} \mathrm{S}, 5^{\circ} 52^{\prime} \mathrm{W}\right)$, General Câmara, on 27 November 1997, and Polo Petroquímico de Triunfo, on 27 November 2000 (GAB, I. Accordi). A nest with four nestlings attended by at least one adult was found in January 2004 at Arroio Cadeia (31 33 'S, $51^{\circ} 33^{\prime} \mathrm{W}$ ), Morro Redondo (GNM, RAD, J. M. Schlee Jr.). The nest, placed about $1.5 \mathrm{~m}$ above ground, was a deep cup supported by the base of the leaves of the pteridophyte Dicksonia sellowiana (Dicksoniaceae).

Mouse-colored Tapaculo Scytalopus speluncae. Pair carrying food to and removing fecal sacs from a nest hidden among rocks covered with dense herbaceous vegetation on road embankment south of São José do Herval ( $\left.29^{\circ} 31^{\prime} \mathrm{S}, 51^{\circ} 00^{\prime} \mathrm{W}\right), 4$ November 1989 (young heard from nest); slopes nearby covered with semievergreen forest, mostly secondary (GAB).

Planalto Woodcreeper Dendrocolaptes platyrostris. Nest in house overhang in forested area near Picada Verão, Sapiranga, containing at least two young, 27 November 1992. Another nest, with three nestlings, built on bottom of empty lard can inside shed in rural area, at Monte Alverne, Santa Cruz do Sul, January 1994 (GAB).

Curve-billed Reedhaunter Limnornis curvirostris. Two nests with eggs attended by adults seen at Pontal da Barra, Pelotas, in late 1991 (two eggs) and on 26 October 1994 (one egg). Two territorial pairs fed well-grown young with dark-tipped orange bills at the same place in late December 1996 and early January 1997 (GNM). Another active nest with two eggs was photographed at 
Banhado do Capão Seco, Rio Grande, December 1997 (GNM, RAD; WA694140). Nests were large, ovoid structures with a superolateral circular entrance and built of sawgrass Scirpus giganteus (Cyperaceae) leaves attached to sawgrass clumps.

Brown Cacholote Pseudoseisura lophotes. Nestlings inside large nest of sticks were being fed by two adults at Parque Estadual do Espinilho, Barra do Quaraí, 2 December 2010 (MR).

Freckle-breasted Thornbird Phacellodomus striaticollis. Nest built of twigs atop Eryngium pandanifolium (Apiaceae) clump in grassy marsh and containing four white eggs was photographed at $32^{\circ} 18^{\prime} \mathrm{S}, 52^{\circ} 16^{\prime} \mathrm{W}$ near Cassino, Rio Grande, November 1997 (GNM, RAD; WA694799). Nests with eggs and nestlings also seen at Coxilha Grande, Vacaria; Arroio Água Branca, Bom Jesus; and Areal, Quaraí, between November 2008 and January 2009 (MR).

Firewood-gatherer Anumbius annumbi. Pairs of adults on their nests are commonly seen in bushes along roads in sectors of open vegetation throughout the state. Nest containing nestling was found in rural area of Viamão ( $\left.30^{\circ} 05^{\prime} \mathrm{S}, 51^{\circ} 02^{\prime} \mathrm{W}\right)$, November 2009 (DBM).

Gray-bellied Spinetail Synallaxis cinerascens. Short-tailed young following adult seen at Monte Alverne, Santa Cruz do Sul, 10 January 1995 (GAB).

Olive Spinetail Cranioleuca obsoleta. Active nest with three eggs found at FEPAGRO, Eldorado do Sul, 23 August 2006 (MR). The spherical nest had a lateral circular entrance and was placed $2.5 \mathrm{~m}$ high within thin branches and leaves of a Sebastiania commersoniana (Euphorbiaceae) tree.

Swallow-tailed Manakin Chiroxiphia caudata. Females on nest incubating two eggs were seen at Monte Alverne, Santa Cruz do Sul, 11 November 1995 (GAB), and at the Arroio Andrade headwaters (31 27 'S, $52^{\circ} 28^{\prime} \mathrm{W}$ ), Arroio do Padre, February 1996 (GNM, A. Quadros). Nest at Monte Alverne contained two nestlings on 24 November, but was empty four days later; only the female was seen sitting on nest; eggs were horn-colored with abundant brown spots, which in one egg covered the larger end almost altogether. Both nests were cup-shaped (low cup/fork of SimON \& PACHECO, 2005), one placed about $1.5 \mathrm{~m}$ aboveground.

Black-crowned Tityra Tityra inquisitor. A pair accompanied by two stub-tailed young was observed in canopy of small fragment of seasonal broadleaf forest at Estrela ( $\left.29^{\circ} 31^{\prime} \mathrm{S}, 51^{\circ} 57^{\prime} \mathrm{W}\right), 7$ November 1998. Adults chased away other birds that approached the young (e.g., a Tropical Kingbird Tyrannus melancholicus) and performed several times a kind of display as follows: they would launch into the air to fly outward singly or side by side for about $30-40 \mathrm{~m}$, and then return to the same perch, fluttering wings after taking off or on return flight. BELTON (1985) described a similar flight display from a female near its nest (content unknown).

Hooded Berryeater Carpornis cucullata. The nest of this species is undescribed. Nests with eggs and nestlings were found at Cerro das Almas (31 ${ }^{\circ} 46^{\prime} \mathrm{S}$, $52^{\circ} 35^{\prime}$ W), Capão do Leão, between October 1998 and April 2000 (GNM), and at CPCN Pró-Mata, December 1999 (MAURício, in press).

Many-colored Rush-Tyrant Tachuris rubrigastra. Two nests, one abandoned and the other attended by a pair, were found at Banhado do Capão Seco, Rio Grande, November and December 1997. The active nest contained three eggs when discovered and two nestlings and one unhatched egg on a later inspection (GNM, RAD). The egg was collected (MCP 2948). A total of nine nests were found at Pontal da Barra, Pelotas, between December 1997 and January 1998. Two of these had eggs incubated by pairs of adults and the remaining were abandoned (GNM). All nests were subsequently collected (MCP 1139-1147). Additionally, a nest with two eggs found at Lagoa da Embira (32 $58^{\prime}$ 'S, $52^{\circ} 58^{\prime} \mathrm{W}$ ), Santa Vitória do Palmar, on 20 November 2012; at least one adult was seen incubating (MR).

Sepia-capped Flycatcher Leptopogon amaurocephalus. On 10 November 1997, adults visited a nest under overhang of earth bank of a stream at intervals of $20 \mathrm{~min}$ or less to feed young within secondary forest near Santa Cruz do Sul (GAB).

Yellow-olive Flycatcher Tolmomyias sulphurescens. Nest with three young found in the riparian forest of the Rio dos Sinos (29 $\left.44^{\prime} \mathrm{S}, 51^{\circ} 05^{\prime} \mathrm{W}\right)$ at Novo Hamburgo, 11 November 1989 (GAB, H. Grillo). Another nest, discovered on the outskirts of Santa Cruz do Sul, contained nestlings that were being fed by both parents with insects (orthopteran Tettigoniidae on one occasion), 10 November 1997; this nest placed $1.8 \mathrm{~m}$ above a stream within secondary forest. A third nest, found at Monte Alverne, Santa Cruz do Sul, contained three eggs in January 1985 (GAB).

Ochre-faced Tody-Flycatcher Poecilotriccus plumbeiceps. On 15 November 1995, at Pontal da Barra, Pelotas, an adult was entering a cone-shaped nest hanging $1.2 \mathrm{~m}$ above ground, which contained two white, dark spotted eggs (GNM). Nests with young were found in the floodable riverine forest along the Rio dos Sinos at Novo Hamburgo, 11 November 1989 (GAB, H. Grillo), and at the Polo Petroquímico de Triunfo, 19 November 2010 (J. Rosoni, GAB).

Cliff Flycatcher Hirundinea ferruginea. An adult sitting on a cup nest built on a window sill in a shack in grassland and containing small downy nestlings was photographed at Coxilha Alta (31 $\left.26^{\prime} \mathrm{S}, 53^{\circ} 12^{\prime} \mathrm{W}\right)$, Piratini, December 2012 (F. R. Cunha; WA825017, WA825019, WA825020).

Tawny-crowned Pygmy-Tyrant Euscarthmus meloryphus. Nest with two eggs found at FEPAGRO, Eldorado do Sul, 4 November 2005 (MR).

Yellow-bellied Elaenia Elaenia flavogaster. A recently fledged young with short rectrices was photographed at the Polo Petroquímico de Triunfo on 3 
December 2009 (GAB, J. Rosoni, M. S. Pereira).

Highland Elaenia Elaenia obscura. Nest with two eggs found at FEPAGRO, Eldorado do Sul, 27 December 2006 (MR). Eggs white to pinkish with cinnamon streaks/spots on the larger end. Nest was a shallow, compact cup, very small relative to the size of the bird, built primarily with dry grass inflorescences and placed on a vertical fork of a Daphnopsis racemosa (Thymelaeaceae) shrub $1.2 \mathrm{~m}$ aboveground.

Vermilion Flycatcher Pyrocephalus rubinus. A nest containing two downy chicks was photographed at Reserva Biológica do Mato Grande, Arroio Grande, 20 December 2004 (J. M. Schlee Jr.). Two newly fledged young with short rectrices were attended by pair of adults close to their nest on a Vachellia caven (Fabaceae) shrub at Estância Leões ( $30^{\circ} 57^{\prime} \mathrm{S}, 5^{\circ} 28^{\prime} \mathrm{W}$ ), Dom Pedrito, 28 November 2010 (MR).

Euler's Flycatcher Lathrotriccus euleri. Nest found with three eggs on 22 October 2009 at the Polo Petroquímico de Triunfo; it contained a partially feathered nestling on 5 November. In this same area, another nest containing a dead, near-fledging young was discovered on 9 December 2009 (J. Rosoni, GAB). These and two other nests found in Rio Grande do Sul (the content of which could not be determined) shared the same basic architecture: a shallow cup made of flexible stems and filamentous plant materials (e.g., Spanish moss Tillandsia usneoides, Bromeliaceae) resting on a relatively thick layer or "cushion" of green mosses. The nest is placed quite low in small open cavities in crotches, broken stumps, knot holes or slits left by broken branches, or else in rock crevices inside dense forest.

Spectacled Tyrant Hymenops perspicillatus. Nest with one egg found inside grass tussock at Banhado do Capão Seco, Rio Grande, 15 October 2004 (RAD); both the nest (MCP 1516) and the egg (MCP 1684) were collected. Also two nestlings attended by female at nest placed $50 \mathrm{~cm}$ aboveground within dense clumps of Spartina sp. (Poaceae), at Parque Nacional da Lagoa do Peixe, Tavares, 27 September 2011 (MR).

Yellow-browed Tyrant Satrapa icterophrys. Nests with eggs and nestlings recorded at FEPAGRO, Eldorado do Sul, between October and December 20022006 (MR). Also a stub-tailed, newly-fledged young photographed at Lami, Porto Alegre, 12 November 2005 (A. Becker), and three nestlings seen on nest at Colônia

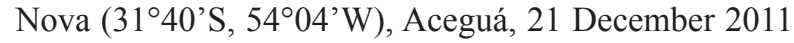
(DBM).

Streaked Flycatcher Myiodynastes maculatus. A hole in vertical snag into which a pair was entering with nest material on 17 October 2012 contained three young with well-advanced feathering on 26 November, at the Jardim Botânico de Porto Alegre (C. M. da Glória). This species usually builds its nest in tree cavities (Sick, 1997; NAROSKY \& SALVADOR, 1998; GUSSONI \& GuARALDO, 2009), but an adult of a pair was observed in incubation posture on a nest of the low cup/base type of Simon \& Pacheco (2005) at the Polo Petroquímico de Triunfo, 9 December 2009. The nest resembled that of a thrush Turdus spp. and was built on semi-horizontal branch of Eucalyptus, having some lateral support from thin vertical twigs. It was made primarily of rizhomes of epiphytic pteridophytes (genus Microgramma) and a few Eucalyptus branches with green leaves (GAB, J. Rosoni). Open cup nests are further mentioned for this species by EulER (1900) and Hilty \& BROWN (1986).

Variegated Flycatcher Empidonomus varius. Copulation observed (22 October 2004) on finished but still empty nest placed $4.8 \mathrm{~m}$ up in fork of small tree in parkland at the Polo Petroquímico de Triunfo. Another nest, containing three eggs, found on the same tree at 6.5 $\mathrm{m}$ from ground, 5 November 2009 (GAB, J. Rosoni). Also nest with nestlings built in horizontal fork about $7 \mathrm{~m}$ aboveground in tall and partially defoliated tree at Santo Amaro, General Câmara, 27 November 1997 (GAB, A. Kindel).

Red-eyed Vireo Vireo olivaceus. At Picada Verão, Sapiranga, a nearly completed nest at which an adult was adding the lining on 29 October 1989 contained two eggs six days later, with incubation underway (GAB). In addition, an adult incubating three eggs in a nest attached to a horizontal branch $1.3 \mathrm{~m}$ high in a Eupatorium polystachyum (Asteraceae) shrub was photographed at Capela do Caravaggio, Vacaria, December 2009 (MR).

Southern Rough-winged Swallow Stelgidopteryx ruficollis. Four nestlings attended by two adults were in a hole in embankment of eroded ravine at Três Cerros ( $\left.31^{\circ} 09^{\prime} \mathrm{S}, 54^{\circ} 18^{\prime} \mathrm{W}\right)$, Dom Pedrito, on 22 December 2010; one young was captured and photographed (RAD). In addition, two adults were bringing food to their young in hole on bank of the Arroio Castelhano $\left(29^{\circ} 33^{\prime} \mathrm{S}, 52^{\circ} 20^{\prime} \mathrm{W}\right)$, Santa Cruz do Sul, on 19 February 1988 (GAB), and a nest with nestlings was found at Capela do Caravaggio, Vacaria, on 9 December 2008 (MR).

Yellow-legged Thrush Turdus flavipes. A tailless, partially feathered fledgling was found on ground in primary foothill forest at Reserva Biológica da Serra Geral, Maquiné, with its presumed mother calling vigorously nearby, on 23 November 2004 (GAB).

Yellowish Pipit Anthus lutescens. A nest containing three eggs attended by an adult (which was observed and identified at close range) was found on a levee of a rice field at Bacopari (30 33'S, 50²6'W), Mostardas, 14 December 2001 (RAD; WA691055). One egg was collected (MCP 1706).

Correndera Pipit Anthus correndera. Nest with two eggs found at a sand spit in the channel connecting the Lagoa dos Patos with the ocean, adjacent to the Molhe Leste ( $\left.32^{\circ} 09^{\prime} \mathrm{S}, 52^{\circ} 04^{\prime} \mathrm{W}\right)$, São José do Norte, December 2001 (LB, R. Both). Another nest with four chicks encountered on 11 November 2010 at the Arroio 
Grande floodplain $\left(32^{\circ} 19^{\prime} \mathrm{S}, 53^{\circ} 01^{\prime} \mathrm{W}\right)$, Arroio Grande (MR). Two additional nests, one with three eggs and one with four, were photographed at Parque Nacional da Lagoa do Peixe, Tavares, 14 January 2010; incubating adults were observed in and out of the nest at close range, allowing positive identification on the basis of plumage (GAB, J. Rosoni); one egg was collected (MCN-O 666).

Hellmayr's Pipit Anthus hellmayri. A nest containing four eggs and attended by an adult was photographed at Arroio do Navio ( $32^{\circ} 17^{\prime} \mathrm{S}, 52^{\circ} 15^{\prime} \mathrm{W}$ ), Cassino, Rio Grande, 11 December 1997 (RAD; WA691051).

Bananaquit Coereba flaveola. In a study of the bird breeding phenology in three areas of the Metropolitan Region of Porto Alegre from August 2009 to February 2010, 20 nests under construction were found between 30 August-22 December, five nests with eggs between 14 September-11 November, and one nest with nestlings on 17 November (J. Rosoni, GAB); three eggs (MCN-O 654-656) and seven abandoned nests (MCN-N 01, $03-07,28)$ were collected. Additionally, two newlyfledged young were captured within the urban area of Porto Alegre and brought to MCN on 5 December 2005 (GAB).

Green-winged Saltator Saltator similis. Nest with three eggs concealed within dense vine tangle at edge of lowland evergreen forest west of Lagoa do Morro

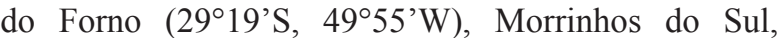
photographed 29 October 2008 (GAB, A. Kindel). Also a nest with two eggs found at FEPAGRO, Eldorado do Sul, 4 November 2005 (MR).

Golden-billed Saltator Saltator aurantiirostris. A cup nest of dry grasses containing three eggs placed $2 \mathrm{~m}$ aboveground in tree was found at Areal, Quaraí, October 2008 (MR).

Ruby-crowned Tanager Tachyphonus coronatus. On 23 January 1992, a female of a pair fed a fledgling with poor flight ability that was begging continuously within primary seasonal forest at Monte Alverne, Santa Cruz do Sul. A female feeding two dependent, femaleplumaged young was observed at the same locality on 13 January 1995 (GAB).

Diademed Tanager Stephanophorus diadematus. Stub-tailed fledgling fed by adult recorded at Cerro das Almas, Capão do Leão, 10 November 1998 (GNM).

Red-crested Cardinal Paroaria coronata. A nest with one well-grown nestling was found at Cabanha Barbieri $\left(30^{\circ} 56^{\prime} \mathrm{S}, 54^{\circ} 22^{\prime} \mathrm{W}\right)$, Dom Pedrito, on 7 November 2011 (DBM), and another nest with three downy young was discovered at Fazenda Bela Vista $\left(30^{\circ} 25^{\prime} \mathrm{S}, 55^{\circ} 38^{\prime} \mathrm{W}\right)$, Santana do Livramento, on 28 November 2012 (GAB, A. M. Lima). In addition, three recently fledged birds with remiges not fully grown were mist-netted on 15-16 February 2012 at Ilha do Taquari

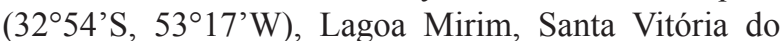
Palmar (LB, F. A. Faria, H. Assis, A. C. C. M. Canary). Yellow-billed Cardinal Paroaria capitata.
Nest with three eggs attached $1.2 \mathrm{~m}$ above still water to horizontal fork of outer branch of a willow Salix humboldtiana (Salicaceae), found at the Polo Petroquímico de Triunfo on 21 November 2008 (GAB, M. da S. Pereira). This record documents the reproduction of the population recently established in the eastern portion of the state, which was presumably introduced (see BENCKE et al., 2010).

Red-crested Finch Lanio cucullatus. Shallow cup nest with four nestlings found at FEPAGRO, Eldorado do Sul, 12 December 2003 (MR).

Black-goggled Tanager Lanio melanops. Afledgling with short tail and fleshy rictus was accompanied by two female-plumaged adults at Monte Alverne, Santa Cruz do Sul, 22 January 1992 (GAB).

Green-headed Tanager Tangara seledon. On 11 October 2004, a presumed female was attending a nest hidden among bromeliads forming dense clump around the trunk of a jerivá palm Arecastrum romanzoffianum (Arecaceae), below an active nesting colony of Redrumped Caciques Cacicus haemorrhous in the Yucumã waterfall area at Parque Estadual do Turvo. The nest, installed $1.7 \mathrm{~m}$ above ground and well protected by the spiny leaves of the bromeliads, was a fairly high, tightly woven cup made of elongated dry leaves, spiral tendrils, rhizomes and a few twigs, having some bark covering it externally and a lining of fine rootlets and rhizomorphs. Eggs (at least two) were whitish in ground color, densely spotted and speckled with lilac (GAB). Also at Parque Estadual do Turvo, a female was incubating two eggs in nest in bromeliad, 13 October 2006 (MR).

Uniform Finch Haplospiza unicolor. On 14 March 2006, a newly fledged young flew awkwardly to a bush in the understory of foothill primary forest at Reserva Biológica da Serra Geral, Maquiné, with a female performing distraction display nearby, during mast seeding of Merostachys bamboo (GAB, J. K. Mähler Jr.).

Long-tailed Reed-Finch Donacospiza albifrons. Active nests, one with three eggs and two other with two and three nestlings, found at Arroio Água Branca, Bom Jesus, and Capela do Caravaggio, Vacaria, in November and December (MR). Nests were cup-shaped and built in small Asteraceae bushes (Vernonia chamaedris, Eupatorium polystachyum and E. intermedium), being placed $0.3-0.8 \mathrm{~m}$ above ground in dry grassland area. Two recently fledged young with limited flying capacity and attended by two adults were photographed at Fazenda do Banheiro $\left(32^{\circ} 15^{\prime} \mathrm{S}, 53^{\circ} 12^{\prime} \mathrm{W}\right)$, Arroio Grande, 26 November 2007 (RAD; WA692712).

Black-and-rufous Warbling-Finch Poospiza nigrorufa. Nest with three eggs found at Macena (283'소 $\left.50^{\circ} 46^{\prime} \mathrm{W}\right)$, Vacaria, October 2005 (MR). The nest was a cup built in the dense upper foliage of shrub $1 \mathrm{~m}$ above a stream; eggs whitish to light turquoise with scattered brown and dark gray spots.

Gray-throated Warbling-Finch Poospiza cabanisi. 
Nest with three eggs found at Capela do Caravaggio, Vacaria, 28 November 2008 (MR). The nest was a shallow cup made of dry grasses, inflorescences and roots, being attached to a small bush $1.9 \mathrm{~m}$ above ground on the edge of a forest patch; eggs bluish to tourquoise with blackish spots/streaks.

Black-capped Warbling-Finch Poospiza melanoleuca. A fledgling with all-gray plumage and no black on head, and with rectrices one-quarter to one-third grown was seen in company of adult on 13 October 1997 north of Uruguaiana $\left(29^{\circ} 46^{\prime} \mathrm{S}, 5^{\circ} 00^{\prime} \mathrm{W}\right.$; GAB). Also a young barely capable of flight attended by adults seen at Parque Estadual do Espinilho, Barra do Quaraí, February 2005 (MR, C. S. Fontana).

Wedge-tailed Grass-Finch Emberizoides herbicola. Nest with two eggs found at Areal, Quaraí, 6 February 2006 (MR). Eggs whitish with cinnamon spots, mainly on the larger end.

Gray-cheeked Grass-Finch Emberizoides ypiranganus. Nest with two eggs found at Arroio Água Branca, Bom Jesus; another nest containing three eggs observed at $28^{\circ} 36^{\prime} \mathrm{S}, 50^{\circ} 02^{\prime} \mathrm{W}$ near the Rio Silveira, São José dos Ausentes. Both nests found between October and December 2005 (MR). Nests were placed 20-30 cm aboveground in clumps of Andropogon lateralis and Saccharum angustifolium (Poaceae); eggs white to pinkish with brown to grayish spots.

Great Pampa-Finch Embernagra platensis. A nest with eggs and another with nestlings were found, respectively, in a marsh near the Rio Socorro at Coxilha Grande, Vacaria (November 2006), and in a marsh near the Arroio Água Branca, Bom Jesus (December 2006) (MR). A nest hidden under clump of Baccharis cf. trimera (Asteraceae) and B. coridifolia (Asteraceae) in area with $50 \%$ grazed pasture and 50\% low bushy clumps some $15 \mathrm{~m}$ from edge of swale-marsh with gravatás Eryngium pandanifolium (Apiaceae) was

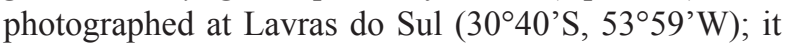
contained three eggs with incubation underway on 20 December 2007 (GAB, RAD). A nest hidden in tussock at Arroio do Navio, Rio Grande, containing three eggs of this species and two of Molothrus bonariensis, was photographed on 26 October 1997 (RAD; WA692717); an adult was incubating.

Lined Seedeater Sporophila lineola. A pair attending a nest with young was filmed and photographed by $\mathrm{C}$. Mansan at Maquiné $\left(29^{\circ} 41^{\prime} \mathrm{S}, 50^{\circ} 11^{\prime} \mathrm{W}\right)$, late in March 2011. The nest, collected on 30 March (MCN-N 071), was a loosely woven, thin-walled cup attached $3.25 \mathrm{~m}$ up to fork of twig in outer branch of a cultivated mango Mangifera indica (Anacardiaceae), and was made of fine roots and a few artificial filaments.

Capped Seedeater Sporophila bouvreuil. Nest with one egg found $30 \mathrm{~cm}$ aboveground in Eupatorium sp. (Asteraceae) bush at Morro Grande (28 $\left.27^{\prime} \mathrm{S}, 51^{\circ} 04^{\prime} \mathrm{W}\right)$, Vacaria, 18 December 2012. Other two nests, each containing a 3-4 day-old nestling, were found among dry grasses attached 15 and $35 \mathrm{~cm}$ aboveground near a marsh at São Francisco de Assis (2936'S, 54⒌'W), 27 December 2012. Detailed nest descriptions will be published elsewhere. Additionally, a stub-tailed fledgling with poor flight ability was being fed by adult male at Ituim (2840’S, 51¹3'W), Ipê, 19 February 2010 (MR). The taxon involved is $S$. $b$. pileata, for which specific status has been recently proposed (MACHADO \& SILVEIRA, 2011).

Marsh Seedeater Sporophila palustris. A halfsized fledgling with very short wings and tail, capable of flying distances of no more than 4-5 $\mathrm{m}$ and accompanied by a female-plumaged individual, was hand-caught on 9 January 2003 at Banhado do Maçarico (32 $18^{\circ} \mathrm{S}$, $52^{\circ} 25^{\prime} \mathrm{W}$ ), Rio Grande (GNM, RAD, C. M. Joenck, C. S. Fontana). This information complements the report on this young in BENCKE et al. (2003). Additionally, nests with eggs and fledglings were studied by VIZENTIN-BUGONI et al. (2013) on the summer of 2008-2009 at Reserva Biológica do Mato Grande, Arroio Grande, where two nests and two eggs were collected (MCP 3003, 3004).

Chestnut Seedeater Sporophila cinnamomea. A nest containing two small chicks was photographed at Fazenda Seival $\left(31^{\circ} 21^{\prime} \mathrm{S}, 53^{\circ} 42^{\prime} \mathrm{W}\right)$, Candiota, on 18 January 2007 (RAD, M. S. S. Gonçalves; WA696202). The nest was a deep cup (high cup/lateral of SimON \& PACHECO, 2005) woven with fine grass stems, inflorescences and some spider webs, and was attached some $50 \mathrm{~cm}$ from the ground to an Asteraceae (probably genus Pluchea) in area of dense grass cover. Measurements of this nest are as follows (in centimeters): internal diameter 4.3, external diameter 4.9, depth of the incubatory chamber 4.0, external (total) height 5.3. The supporting plant was $100 \mathrm{~cm}$ tall; nest found in dry grassland with vegetation $80-90 \mathrm{~cm}$ high, adjacent to humid terrain bordering a small creek. A pair of adults was nearby, the female-plumaged bird having flown from the nest upon approach. A similarly shaped nest with two eggs attached to a large forb was found near Fazenda Cerro do Tigre (29³9'S, 55²3'W), Alegrete, on 8 December 2012 (DBM). Its measurements were: internal diameter 4.2, external diameter 6.2, depth of the incubatory chamber 3.7 , external height 5.9 . It was placed $34 \mathrm{~cm}$ from the ground on a supporting plant about $65 \mathrm{~cm}$ tall in grassland with vegetation $50-60 \mathrm{~cm}$ high bordering a creek. Both nests matched the pattern described for other Sporophila of the capuchino group (DE LA PeÑA, 2005; Rovedder \& FontanA, 2012). Another nest was collected at Assentamento Santa Maria do Ibicuí (29²8'S, 53³9’W), Manoel Viana, on 3 February 2006, by M. Krügel (MCP 1782). Additionally, a fledgling with very short wings and tail, capable of fluttering small distances and attended by femaleplumaged bird, was hand-caught and photographed on 28 December 2005 at Fazenda Aroeira A (31 46's, $53^{\circ} 50^{\prime} \mathrm{W}$ ), Candiota (RAD, M. S. S. Gonçalves, C. B. Andretti).

Red-crowned Ant-Tanager Habia rubica. 
Cup-shaped nest with thick walls found $1.9 \mathrm{~m}$ up in semideciduous forest at Campo Bom (29³8' $\mathrm{S}$, $\left.51^{\circ} 03^{\prime} \mathrm{W}\right)$, with female incubating eggs, December 2005 (I. Franz).

Indigo Grosbeak Cyanoloxia glaucocaerulea. One nest with two eggs attached $1.6 \mathrm{~m}$ up to hanging clump of rhizomes of epiphytic pteridophytes (genus Microgramma, Polypodiaceae) in interior of $8 \mathrm{~m}$ high restinga forest was found at Barra do Ribeiro (30 $24^{\circ} \mathrm{S}$, $\left.51^{\circ} 12^{\prime} \mathrm{W}\right), 17$ December 1997 . The nest was a deep cup, made of twigs and fine roots. Eggs light blue-gray in ground color, coarsely speckled with vinaceous, having the larger end almost entirely vinaceous. Adults fed on the developed ovaries of Justicia sp. (Acanthaceae) on the occasion (GAB). Another nest with eggs was photographed in December 2010 near the mouth of the Rio Cerquinha (2827'S, 50¹6'W), Bom Jesus (MR).

Masked Yellowthroat Geothlypis aequinoctialis. Nests with three nestlings photographed in December 2009 and January 2010 in marsh near Arroio Água Branca, Bom Jesus, and at Capela do Caravaggio, Vacaria, respectively (MR). Another nest, built on the ground and hidden within dense mat of exotic grass on small embankment at the Jardim Botânico de Porto Alegre, was discovered with one egg on 6 November 2009 and contained three eggs on 9 November; it was subsequently abandoned and collected along with two eggs (MCN-N 015; MCN-O 661, 662; J. Rosoni, GAB).

Golden-winged Cacique Cacicus chrysopterus. Old nests of this fairly common species are frequently encountered in forests and woodlands of Rio Grande do Sul, since they are conspicuous and relatively resistant to weathering and decomposition. A nest with nestlings was suspended about $4 \mathrm{~m}$ above artificial channel within low secondary forest with many exotic tree species at the Polo Petroquímico de Triunfo, 21 October 2004; two adults fed the young with fruits, almost certainly of the native shrub Allophylus edulis (Sapindaceae) on one occasion; in the early afternoon, there were 5-6 visits to the nest within 30 min observation (GAB).

Red-rumped Cacique Cacicus haemorrhous. Several nesting colonies, occupied for years, are known from the Parque Estadual do Turvo. In late December 2003, the colony next to the park headquarters at Centro Novo included at least 3-4 active nests among dozens of others seemingly inactive ones, all of which pending from the tips of the leaves of a jerivá palm Arecastrum romanzoffianum (Arecaceae). Small-sized adults, presumably females, entered active nests repeatedly to feed young with arils of camboatá-vermelho tree Cupania vernalis (Sapindaceae) and insects. The entire colony comprised about 50 birds (GAB, J. K. Mähler Jr.).

Variable Oriole Icterus pyrrhopterus. Nest containing two eggs (one of which apparently of Molothrus bonariensis) collected on 5 December 2012 (MCN-N 101; MCN-O 746, 747), at the Jardim
Botânico de Porto Alegre (GAB, C. M. da Glória). This nest was discovered on 8 November, when it was being attended by two adults and contained at least two nestlings which supposedly fledged in the meantime.

Yellow-rumped Marshbird Pseudoleistes guirahuro. Fragments of eggshell and embryo (MCP 69, 726) obtained at an untraced locality in São Francisco de Paula on 27 January 1998 (C. S. Fontana).

White-browed Blackbird Sturnella superciliaris. Nest built of fine twigs and grasses containing three eggs (one collected; MCP 2947) hidden in the base of grass tussock at $32^{\circ} 18^{\prime} \mathrm{S}, 52^{\circ} 16^{\prime} \mathrm{W}$ near Cassino, Rio Grande, 4 January 1998 (RAD). In addition, a nest with four nestlings found at Fazenda Carvão ( $30^{\circ} 02^{\prime}$ S, 55 59' W), Alegrete, 4 February 2013 (DBM).

Purple-throated Euphonia Euphonia chlorotica. A domed nest attended by a pair was discovered in early September 2009 at the Jardim Botânico de Porto Alegre; two nestlings fledged from it upon approach on 7 October. The nest was reoccupied, presumably by the same pair, and contained three eggs on 21 October, but on 6 November was found depredated with an unhatched egg inside and a dead, naked young hanging from its entrance; nest, egg and nestling were collected (MCN-O 657, MCN-N 08). In the following year, another nest with two feathered young was found in the same place on 4 October (J. Rosoni, GAB).

Blue-napped Chlorophonia Chlorophonia cyanea. A nest with three eggs was found at Reserva Biológica da Serra Geral, Maquiné, 14 December 2004 (GAB). The nest was a soft, enclosed, taller than wide structure loosely adhered about $1 \mathrm{~m}$ up to a vertical rocky bank within primary evergreen forest (closed/ovoid/lateral type of Simon \& PACHECO, 2005). It had a front entrance and was made of fine roots and covered with mosses and Selaginellaceae ferns. Male and female were nearby, but only the latter was seen entering the nest. Eggs were white with purple speckles that tended to vinaceous at the larger end.

House Sparrow Passer domesticus. Nests in buildings in urban areas throughout the state. Nestlings fallen from nests were collected at Porto Alegre on 11 November 1999, 20 October and 23 November 2005 (MCP 626, 627, 1659, 1670; C. S. Fontana, U. B. Rasquin, C. E. Rovedder). At Estrela, a female was feeding well-developed young in nest box on 5-7 October 2007 (GAB).

\section{DISCUSSION}

We found effective evidence of breeding for 291 bird species in Rio Grande do Sul. This corresponds to $54.7 \%$ of the 532 species which could potentially breed in the state (after BencKe et al., 2010). BeLton (1994) considered that reasonable evidence of breeding was available for 355 species. This substantial difference results from the fact that this author accepted as sufficient 
various types of indirect evidence not accepted by us, including enlarged gonads (both testes and ovaries), nests under construction, young with good flight capability and some types of display behavior [see appendix A in BeLton $(1985,1994)$ in cross reference with text]. Furthermore, the confirmation of a given species as resident on the basis of occurrence data apparently acted as an auxiliary criterion for Belton's judgments as to its breeding status in the state.

Although the current total of species which have effective evidence of breeding in Rio Grande do Sul represents an increase of about $70 \%$ compared to the previous assessment, this figure is far from satisfactory considering that Rio Grande do Sul is one of the most thoroughly sampled of the Brazilian states with respect to its avifauna. Supporting this notion is the fact that for several common species, including abundant ones as the Roadside Hawk Rupornis magnirostris, Rufous-browed Peppershrike Cyclarhis gujanensis and Tropical Parula Parula pitiayumi, among others, there is no effective evidence of breeding published to date.

Of the species reported to breed in the state postBelton (1994), most were resident taxa expected to breed in Rio Grande do Sul, several having some indirect evidence of breeding (e.g., enlarged gonads) already reported in Belton's contributions. Others, namely the American Kestrel, Brown-hooded Gull, Gull-billed Tern, Bananaquit and the Black-capped Warbling-Finch, were known to nest in the state (Belton, 1994; MaURício \& DiAs, 1996; CRISTOFOLI et al., 2008), although contents of these nests or other details that could confirm their breeding status were not given. Evidence of breeding based on sightings of fledglings were previously known for species such as the Yellow-legged Thrush and the Black-and-rufous Warbling-Finch (BeLTON, 1994; MÄHLER JR. et al., 1996), but lack of details regarding the flight capability of young birds hindered an inequivocal evaluation of these records.

We were also able to elucidate the breeding status of the Plumbeous Rail in the state. BELTON (1984) found a nest with downy chicks and eggs in the Gramado area and, based on a fleeting glimpse of the adult, had the impression it was a Blackish Rail Pardirallus nigricans, but was not sure of this identification because the Plumbeous Rail was also present in the same area. Since NARANJo (1991) found that a downy chick of the Blackish Rail he encountered in the Cauca Valley of Colombia was distinct from that described by BeLtoN (1984) in having coral red instead of black bill and legs, he suggested the chick from Gramado could be of a Plumbeous Rail. Based on the finding and suggestion of NARANJo (1991), BELTON (1994) later regarded that the chick he described from Gramado was apparently of the Plumbeous Rail. However, NARANJo's (1991) description applies only to $P$. n. caucae, a taxon endemic to the Cauca Valley (TAYLOR, 1996), since the downy chick of the nominate form of the Blackish Rail has black bill and legs similar to the Plumbeous Rail (see photographs of chicks of both species at the WikiAves web site). Therefore, we conclude that the breeding record of BELTON $(1984,1994)$ cannot be attributed with certainty to either the Plumbeous or the Blackish Rail. Consequently, effective evidence of breeding in the state is still lacking for the latter.

Our new information includes details on the breeding biology of several poorly-known species. The previous description of the nest of the Indigo Grosbeak, for example, lacks details on nest placement and architecture (HARTERT \& VenturI, 1909). Other poorlyknown species for which we present new breeding information include rails, crakes, swifts, pipits and seedeaters.

Some common and widespread species found year-round in Rio Grande do Sul also lacked adequate evidence of breeding in the state. Vultures, the Greenbarred Woodpecker, Firewood-gatherer, Great PampaFinch and Red-crested Cardinal are included in this group. Also surprising is the lack of previous detailed breeding information for synanthropic species such as the Rock Pigeon and House Sparrow. It is likely that detailed breeding evidences of these widespread birds were simply overlooked by observers or deemed too trivial and thus unworthy of recording, because of their commonness.

As expected, the bulk of our new records fall within the austral spring and summer, which is the main breeding season for birds in southern Brazil (Belton, 1994; BENCKE, 1996). Notable exceptions are the Smallbilled Tinamou, Tataupa Tinamou, Neotropic Cormorant, South American Snipe, and Rock Dove, which were recorded breeding during the autumn and winter. We were able to confirm the winter nesting of the South American Snipe in the state, previously suspected on the basis of reports from local hunters (BELTON, 1984). Cool-season breeding of the South American Snipe has been documented also in Uruguay (BARLOw, 1967) and Argentina (DE LA PEÑA, 1987). Winter breeding of the Neotropic Cormorant has also been recorded in Argentina and south-western Brazil (BARQuete et al., 2008). Whether these species breed year-round or mostly in fall-winter period in south Brazil remains to be determined.

Breeding records for the Red Shoveler, Blackheaded Duck, Mouse-colored Tapaculo, Spectacled Tyrant and Correndera Pipit are the first confirmed evidences of reproduction in the Brazilian territory. Both ducks, the Cinereous Harrier and the Many-colored Rush-Tyrant were previously considered non-breeding austral (winter) migrants in Rio Grande do Sul. The new information presented here and elsewhere (e.g., BENCKE et al., 2003) allows for a significant shift in their status of occurrence, since at least part of their populations are now known to breed in the state and may be year-round residents. 
For a few other species with data published or obtained after BELTON (1994) there is evidence of breeding range expansion in the recent years. Such is the case of the Yellow-crowned Night Heron and the Little Blue Heron, which until recently had in the mangroves of Santa Catarina their southern limit of breeding but are now known to breed in the extreme south of Rio Grande do Sul (GIANUCA, 2007; GianUCA et al., 2011, 2012), and also of the Lined Seedeater (BENCKE, 2010). However, the lack of historical breeding data for most species precludes the evaluation of range extension/contraction for most species, either by habitat loss, climate change or any other natural or anthropogenic factors.

We consider that the simple approach of accepting as definitive evidence of breeding data other than nests with egg(s)/nestlings and young with limited mobility misleads the real knowledge of the breeding status of the avifauna of a region, giving a false impression that adequate information exists for a large proportion of the species. This false idea, in turn, may led observers to underestimate the importance of spending more time and effort to obtain valuable data when the opportunity arises.

Although our restrictive criteria for acceptance of breeding evidence may sound too rigid or purely bureaucratic, it may be viewed as valid within the Brazilian reality for a simple reason: unlike North America and Europe, where the culture of birdwatching is widespread and thousands of observers are routinely involved in breeding bird surveys, in South America the limited number of observers and ornithologists precludes rapid advances in the knowledge of bird reproductive biology and phenology. In proposing narrow criteria we are encouraging and, above all, instigating students, amateur observers (including the growing number of bird photographers) and professional ornithologists to look for and document breeding events in such a way that within a few years we can have a nearly complete list of breeders and a broader picture about the breeding distribution of the avifauna in Rio Grande do Sul. The current study is a first step towards a bird breeding atlas, a key tool for the conservation of birds and their habitats. Such atlases are available in several countries and regions where birdwatching is well-developed, e.g. Europe (HaGEMEIJER \& BlaIR, 1997) and Falkland Islands (Woods \& Woods, 1997).

Acknowledgments. We are most grateful to I. A. Accordi, C. B. Andretti, H. Assis, C. N. Barreto, V. A. G. Bastazini, A. Becker, C. Beier, A. Bomm, E. S. Borsato, R. Both, M. D. M. Burns, C. P. Calabuig, A. C. Canary, F. R. Cunha, P. Develey, M. A. Efe, E. Endrigo, F. A. Faria, C. S. Fontana, I. Franz, C. M. da Glória, A. C. F. Gomes-Jr., M. S. S. Gonçalves, H. Grillo, C. M. Joenck, A. Kindel, C. N. Kuhn, J. K. Mähler Jr., C. Mansan, R. Marques, D. Meller, A. de MendonçaLima, A. Osório, M. Pairet, M. da S. Pereira, A. S. Peter, A. Quadros, U. B. Rasquin, S. Ribeiro, J. Rosoni, C. E. Rovedder, J. Sanabria, S. B. Scherer, J. M. Schlee Jr., C. A. Schwertner, J. Vizentin-Bugoni and F. Zilio for sharing unpublished information of several species. R. S. Ferrer and J. M. Schlee Jr. helped with plant species identification. GNM is supported by a post-doctoral grant from Coordenação de Aperfeiçoamento de Pessoal de Nível Superior (CAPES) and Universidade Federal do Rio Grande (FURG). LB is research fellow from CNPq (Proc. 308697/2012-0) GAB thanks the administration of the Estação Ambiental Braskem, in the Polo Petroquímico de Triunfo, for permission to publish information gathered during the monitoring program of the area. Cyro M. da Glória provided the identification of lichens used in one nest.

\section{REFERENCES}

AzPiroz, A. 2001. Aves del Uruguay. Lista e introducción a su biología y conservación. Montevideo, Aves Uruguay, GUPECA $104 p$.

BARlow, J. C. 1967. Autumnal breeding of the Paraguay Snipe in Uruguay. Auk 84(3):421-422.

Barquete, V.; Vooren, C. M. \& Bugoni, L. 2008. Seasonal abundance of the Neotropic Cormorant Phalacrocorax brasilianus at Lagoa dos Patos Estuary, Southern Brazil. Hornero 23(1):15-22.

Belton, W. 1984. Birds of Rio Grande do Sul, Brazil. Part 1: Rheidae through Furnariidae. Bulletin of the American Museum of Natural History 178(4):369-636.

. 1985. Birds of Rio Grande do Sul, Brazil. Part 2: Formicariidae through Corvidae. Bulletin of the American Museum of Natura History 180(1):1-242.

1994. Aves do Rio Grande do Sul, distribuição e biologia. São Leopoldo, Unisinos. 584p.

Bencke, G. A. 1995. The nest of the Grey-headed Flycatcher Mionectes rufiventris. Bulletin of the British Ornithologists' Club 115(2):105-108.

1996. Annotated list of birds of Monte Alverne, central Rio Grande do Sul. Acta Biologica Leopoldensia 18(1):17-42.

1998. Notes on the breeding of Blue-bellied Parrot Triclaria malachitacea. Cotinga 10(1):71-78.

2010. New and significant bird records from Rio Grande do Sul, Brazil, with comments on biogeography and conservation of the southern Brazilian avifauna. Iheringia, Série Zoologia 100(4):391-402.

Bencke, G. A.; Fontana, C. S.; Mähler-Jr., J. K. F. \& Joenck, C. M. 2001. First description of the nest of the Brown-breasted PygmyTyrant (Hemitriccus obsoletus) and additional information on the nesting of the Striolated Tit-Spinetail (Leptasthenura striolata). Ornitología Neotropical 12(1):1-9.

Bencke, G. A.; Fontana, C. S.; Dias, R. A.; Maurício, G. N. \& Mähler-Jr, J. K. F. 2003. Aves. In: Fontana, C. S.; Bencke, G A. \& REIS, R. E. eds. Livro vermelho da fauna ameaçada de extinção no Rio Grande do Sul. Porto Alegre, Edipucrs. p.189479.

Bencke, G. A.; Dias, R. A.; Bugoni, L.; Agne, C. E.; Fontana, C. S.; Maurício, G. N. \& Machado, D. 2010. Revisão e atualização da lista das aves do Rio Grande do Sul, Brasil. Iheringia, Série Zoologia 100(4):519-556.

Biancalana, R. N.; Nogueira, W.; Bessa, R.; Pioli, D.; Albano, C. \& LeEs, A. C. 2012. Range extensions and breeding biology observations of the Sooty Swift (Cypseloides fumigatus) in the states of Bahia, Goiás, Minas Gerais and Tocantins. Revista Brasileira de Ornitologia 20(2):87-92.

BINFORD, L. C. 1973. A short method for treating avian breeding data in regional accounts. Wilson Bulletin 85(2):244-246.

Camilotti, V. L.; Krügel, M. M. \& Hartz, S. M. 2008. Nidificação de Circus cinereus (Aves, Accipitridae) na região da Fronteira Oeste do Rio Grande do Sul, Brasil. Revista Brasileira de Ornitologia 16(4):363-365.

Chantler, P. 2000. Swifts. A guide to the swifts and treeswifts of the world. 2ed. New Haven, Yale University Press. 272p.

Collins, C. T. 1963. The "downy" nestling plumage of swifts of the genus Cypseloides. Condor 65(4):324-328.

Cristofoli, S. I.; Santos, C. R.; Garcia, S. A. \& Sander, M. 2008 Composição do ninho de cambacica: Coereba flaveola Linnaeus, 1758 (Aves: Emberezidae). Biodiversidade Pampeana 6(1):30-33.

DE LA PEÑA, M. R. 1987. Nidos y huevos de aves argentinas. Santa Fe, LUX S.R.L. 229p.

2005. Reproducción de las aves argentinas (con descripción de pichones). Buenos Aires, L.O.L.A. (Monografía 20). 846p.

Dias, R. A. \& Burger, M. I. 2005. A assembléia de aves de áreas 
úmidas em dois sistemas de cultivo de arroz irrigado no extremo sul do Brasil. Ararajuba 13(1):63-80.

Dias, R. A. \& Fontana, C. S. 2002. Distribuição, biologia, ecologia e conservação do cisne-de-pescoço-preto Cygnus melanocorypha, $\mathrm{e}$ da capororoca Coscoroba coscoroba, no Brasil. In: SeIJAS, S. M. org. Censo Neotropical de Cisnes: Conteo de Cisnes de Cuello Negro (Cygnus melancoryphus) y Coscorobas (Coscoroba coscoroba) en Argentina, Brasil y Uruguay. Periodo 19982000. Buenos Aires, L.O.L.A. p. 1-20.

Dias, R. A.; Gonçalves, M. S. S. \& Bastazini, V. A. G. 2009. First nesting record of the Bay-Capped Wren-Spinetail Spartonoica maluroides (Aves, Furnariidae) in Brazil, with nest and nestling descriptions and notes on breeding behavior. Iheringia, Série Zoologia 99(4):449-455.

Efe, M. A.; Bugoni, L.; Mohr, L. V.; Scherer, A.; Scherer, S. B. \& BAIRRO, O. P. 2001. First-known record of breeding for the Black Skimmer (Rynchops niger) in a mixed colony in Ibicuí River, Rio Grande do Sul state, southern Brazil. International Journal of Ornithology 4(2):103-107.

Endrigo, E. 2010. Aves do Pampa. São Paulo, Aves \& Fotos Editora. 224p.

Euler, C. 1900. Descripção de ninhos e ovos de aves do Brazil. Revista do Museu Paulista 4(1):9-148.

FontanA, C. S. 1998. Description of the nest and eggs of the Blackand-white Monjita Heteroxolmis dominicana. Cotinga 8(1):79-81.

Fontana, C. S.; Joenck, C. M. \& Mähler-JR., J. K. F. 2000. Description of the nest and eggs of the Shear-tailed Gray-Tyrant (Muscipipra vetula) and considerations on its historical ecology implications. Ornitología Neotropical 11(2):169-172.

Fontana, C. S.; Repenning, M. \& Rovedder, C. E. 2009. Fauna terrestre: Aves. In: BoldRINI, I. org. Biodiversidade do Planalto das Araucárias. Brasília, MMA. p.159-208.

FranZ, I. 2013. On the nest, eggs and nestlings of the Short-tailed Antthrush (Chamaeza campanisona). Revista Brasileira de Ornitologia 21(1):101-104.

GiANUCA, D. 2007. Ocorrência sazonal e reprodução do Socócaranguejeiro Nyctanassa violacea no estuário da Lagoa dos Patos (RS, Brasil), novo limite sul da sua distribuição geográfica. Revista Brasileira de Ornitologia 15(3):464-467.

Gianuca, D.; Branco, J. O. \& Vooren, C. M. 2011. Notes on breeding by Yellow-crowned Night Heron Nyctanassa violacea in southern Brazil. Cotinga 33(1):63-72.

Gianuca, D.; Gianuca, A. T. \& Vooren, C. M. 2012. Abundance, breeding and food of the Little Blue Heron Egretta caerulea (Aves, Ardeidae) in the Patos lagoon estuary, a recently colonized area in southern Brazil. Iheringia, Série Zoologia 102(1):19-25.

Gussoni, C. O. A. \& Guaraldo, A. C. 2009. Observações sobre a biologia reprodutiva e alimentação do bem-te-vi-rajado (Myiodynastes maculatus) (Statius Muller, 1776) no município de Rio Claro e arredores, SP. Atualidades Ornitológicas 148(1):1213.

Hagemeijer, W. J. M. \& Blair, M. J. 1997. The EBBC Atlas of European breeding birds: their distribution and abundance. London, Poyser. 903p.

Hartert, E. \& Venturi, S. 1909. Notes sur les Oiseaux de la République Argentine. Novitates Zoologicae 16(2):159-267.

Hilty, S. L. \& Brown, W. L. 1986. A guide to the birds of Colombia. Princeton, Princeton University Press. 996p.

Hoffmann, D. \& Krügel, M. M. 2007. Biologia reprodutiva de Elaenia spectabilis Pelzeln, 1868 (Aves, Tyrannidae) no município de Santa Maria, Rio Grande do Sul, Brasil. Revista Brasileira de Ornitologia 15(3):453-456.

IpPi, S.; Vasquez, R. A.; Moreno, J.; Merino, S. \& Villavicencio, C. P. 2012. Breeding biology of the Southern House Wren (Troglodytes aedon chilensis) on Chiloé Island, southern Chile. Wilson Journal of Ornithology 124(3):531-537.

Joenck, C. M.; Zilio, F. \& Mendonç-Lima, A. First record of breeding of the Ornate Hawk-Eagle (Spizaetus ornatus) (Accipitridae) in southern Brazil. Hornero 26(2) (In press).

KRÜGEL, M. M. 2003. Registro documentado de Chondrohierax uncinatus (Temminck, 1822) (Falconiformes: Accipitridae) para o Rio Grande do Sul. Ararajuba 11(1):83-84.

Lomascolo, S. B.; Monmany, A. C.; Malizia, A. \& Martin, T. E. 2010. Flexibility in nest-site choice and nesting success of Turdus rufiventris (Turdidae) in a montane forest in northwestern
Argentina. Wilson Journal of Ornithology 122(4):674-680

Machado, E. \& Silveira, L. F. 2011. Plumage variability and taxonomy of the Capped Seedeater Sporophila bouvreuil (Aves: Passeriformes: Emberizidae). Zootaxa 2781(1):49-62.

MÄHLER, J. K. F., JR.; KINDEL, A. \& KINDEL, E. 1996. Lista comentada das espécies de aves da Estação Ecológica do Taim, Rio Grande do Sul, Brasil. Acta Biologica Leopoldensia 18(1):69-113.

Marín, M. \& Stiles, F. G. 1992. On the biology of five species of swifts (Apodidae, Cypseloidinae) in Costa Rica. Proceedings of the Western Foundation of Vertebrate Zoology 4(5):286-357.

Marreis, I. T.; Dalenagare, R. B. \& Sander, M. 2009. Ocorrência de nidificação adaptativa de gavião-relógio (Micrastur semitorquatus Vieillot, 1817) em hábitat antrópico no Rio Grande do Sul. Biodiversidade Pampeana 7(1):47-50

Mársico, M. C. \& Reboreda, J. C. 2008. Differential reproductive success favours strong host preference in a highly specialized brood parasite. Proceedings of the Royal Society, Biological Sciences 275(1650):2499-2506.

Maurício, G. N. First description of the nest of the Hooded Berryeater, Carpornis cucullata. Wilson Journal of Ornithology (In press).

Maurício, G. N. \& Dias, R. A. 1996. Novos registros e extensões de distribuição de aves palustres e costeiras no litoral sul do Rio Grande do Sul. Ararajuba 4(1):47-51.

1998. Range extensions and new records for forest birds in southern Rio Grande do Sul, Brazil. Bulletin of the British Ornithologists' Club 118(1):14-25.

Moreno, J.; Merino, S.; Vasquez, R. A. \& Armesto, J. J. 2005. Breeding biology of the Thorn-tailed Rayadito (Furnariidae) in south-temperate rainforests of Chile. Condor 107(1):69-77.

Naranjo, L. G. 1991. Nest, eggs, and young of the Blackish Rail. Ornitología Neotropical 2(1):47-48.

NARosky, T. \& SAlvador, S. 1998. Nidificación de las aves argentinas. Tyrannidae. Buenos Aires, Asociación Ornitológica del Plata. $135 \mathrm{p}$.

Oliveira, R. G. 1980. Observações sobre a coruja-orelhuda (Rhinoptynx clamator), no Rio Grande do Sul (Aves, Strigidae). Revista Brasileira de Biologia 40(3):599-604.

. 1984. Diferença na cor da íris em dois "caborés-de-orelhas" (Otus choliba Vieillot, 1817), irmãos de ninho. Anais da Sociedade Sul-Riograndense de Ornitologia 5(1):15-19.

Oliveira, S. L. 2011. Aves, Apodidae, Cypseloides senex (Temminck, 1826): Geographical distribution in the state of Rio Grande do Sul, southern Brazil. Check List 7(4):473-475.

Pearman, M.; Areta, J. I.; Roesler, I. \& Bodrati, A. 2010. Confirmation of the Sooty Swift (Cypseloides fumigatus) in Argentina with notes on its nest placement, seasonality, and distribution. Ornitología Neotropical 21(3):351-359.

Remsen, J. V., Jr.; Cadena, C. D.; Jaramillo, A.; Nores, M.; Pacheco, J. F.; Pérez-Emán, J.; Robbins, M. B.; Stiles, F. G.; Stotz, D. F. \& Zimmer, K. J. 2012. A classification of the bird species of South America. American Ornithologists' Union. Available at: $<$ http://www.museum.lsu.edu/ Remsen/SACCBaseline.html $>$. Accessed on: December, 2012.

RePenning, M.; RovedDer, C. E. \& Fontana, C. S. 2010. Distribuição e biologia de aves nos campos de altitude do sul do Planalto Meridional Brasileiro. Revista Brasileira de Ornitologia 18(4):283-306.

Rovedder, C. E. \& Fontana, C. S. 2012. Nest, eggs, and nest placement of the Brazilian endemic Black-bellied Seedeate (Sporophila melanogaster). Wilson Journal of Ornithology 124(1):173-176.

SICK, H. 1997. Ornitologia brasileira. Rio de Janeiro, Nova Fronteira. $862 p$.

Silva, F. \& Fallavena, M. A. B. 1995. Movimentos de dispersão de Platalea ajaja (Aves, Threskiornithidae) detectados através de anilhamento. Revista de Ecología Latinoamericana 2(1-3):19-21.

Simon, J. E. \& Pacheco, S. 2005. On the standardization of nest descriptions of Neotropical birds. Revista Brasileira de Ornitologia 13(2): 143-154

SNyder, N. F. R.; Wiley, J. W. \& KePler, C. B. 1987. The parrots of Luquillo: natural history and conservation of the Puerto Rican Parrot. Los Angeles, Western Foundation of Vertebrate Zoology. 384p.

StarcK, J. M. \& Ricklefs, R. E. 1998. Patterns of development: the altricial-precocial spectrum. In: StARCK, J. M. \& RickLEFs, R. 
E. eds. Avian growth and development: evolution within the altricial-precocial spectrum. New York, Oxford University Press. p.3-30.

TAYlor, P. B. 1996. Family Rallidae. In: Del Hoyo, J.; Elliot, A. \& Sargatal, J. eds. Handbook of the birds of the world. Hoatzin to auks. Barcelona, Lynx Ediciones. v 3, p. 108-209.

Tomazzoni, A. C.; Pedó, E. \& Hartz, S. M. 2004. Food habits of Great Horned Owls (Bubo virginianus) in the breeding season in Lami Biological Reserve, southern Brazil. Ornitología Neotropical 15(2):279-282.

Trejo, A. 2007. Identificación de especies y áreas prioritarias para el estudio de la reproducción de aves rapaces de Argentina. Hornero 22(2):85-96

Tuero, D. T.; Fiordini, V. D. \& ReboredA, J. C. 2007. Effects of Shiny Cowbird parasitism on different components of House
Wren reproductive success. Ibis 149(3):521-529.

Vasconcelos, M. F.; Duca, C. \& Silveira, L. F. 2006. Range extension for Sooty Swift Cypseloides fumigatus, with notes on its nesting in central Brazil. Cotinga 25(1):74-76.

Vizentin-Bugoni. J.; Areta, J. I.; Di Giacomo, A. G.; Di Giacomo, A. S.; Jacobs, F.; Coimbra, M. A. A. \& Dias, R. A. 2013. Breeding biology and conservation of the Marsh Seedeater Sporophila palustris. Bird Conservation International 23(2):147-158.

Weller, M. W. 1967. Notes on plumages and weights of the Blackheaded Duck, Heteronetta atricapilla. Condor 69(2):133-145.

. 1968. The breeding biology of the parasitic Black-headed Duck. Living Bird 7(1):169-207.

Woods, R. W. \& Woods, A. 1997. Atlas of breeding birds of the Falkland Islands. Oswestry, Anthony Nelson. 190p.

Appendix 1. Summary of effective evidences of breeding (see main text for definitions) available for birds in Rio Grande do Sul, Brazil, with respective sources. Categories of breeding evidence: NE, nest with egg(s); NY, nest with young; and DY, dependent young with limited mobility and restricted to the natal area. Scientific names and linear sequence follow BENCKE et al. (2010).

\begin{tabular}{|c|c|c|}
\hline Taxon & Breeding evidence & Source \\
\hline Rhea americana (Linnaeus, 1758) & NE, DY & Belton, 1984 \\
\hline Tinamus solitarius (Vieillot, 1819) & $\mathrm{NE}$ & This study \\
\hline Crypturellus obsoletus (Temminck, 1815) & $\mathrm{NE}$ & This study \\
\hline Crypturellus noctivagus (Wied, 1820) & $\mathrm{NE}$ & BeLton, 1984 \\
\hline Crypturellus parvirostris (Wagler, 1827) & DY & This study \\
\hline Crypturellus tataupa (Temminck, 1815) & DY & This study \\
\hline Rhynchotus rufescens (Temminck, 1815) & NE, DY & This study \\
\hline Nothura maculosa (Temminck, 1815) & NE, DY & Belton, 1984 \\
\hline Chauna torquata (Oken, 1816) & NE, DY & Belton, 1984 \\
\hline Dendrocygna bicolor (Vieillot, 1816) & DY & BeLton, 1984 \\
\hline Dendrocygna viduata (Linnaeus, 1766) & NE, DY & BeLton, 1984 \\
\hline Cygnus melancoryphus (Molina, 1782) & $\mathrm{NE}$ & Belton, 1984 \\
\hline Coscoroba coscoroba (Molina, 1782) & DY & Dias \& Fontana, 2002 \\
\hline Callonetta leucophrys (Vieillot, 1816) & DY & This study \\
\hline Amazonetta brasiliensis (Gmelin, 1789) & NE, DY & Belton, 1984 \\
\hline Anas flavirostris Vieillot, 1816 & NE, DY & Belton, 1984 \\
\hline Anas georgica Gmelin, 1789 & NE, DY & BeLton, 1984 \\
\hline Anas versicolor Vieillot, 1816 & DY & BeLton, 1984 \\
\hline Anas platalea Vieillot, 1816 & DY & This study \\
\hline Netta peposaca (Vieillot, 1816) & DY & Belton, 1984 \\
\hline Heteronetta atricapilla (Merrem, 1841) & NE, DY & This study \\
\hline Nomonyx dominica (Linnaeus, 1766) & DY & Belton, 1984 \\
\hline Ortalis guttata (Spix, 1825) & NE, NY, DY & This study \\
\hline Penelope obscura Temminck, 1815 & DY & Belton, 1984 \\
\hline Aburria jacutinga (Spix, 1825) & NE, DY & BELTON, 1984 \\
\hline Odontophorus capueira (Spix, 1825) & DY & This study \\
\hline Rollandia rolland (Quoy \& Gaimard, 1824) & NE, DY & This study \\
\hline Tachybaptus dominicus (Linnaeus, 1766) & DY & BELton, 1984 \\
\hline Podilymbus podiceps (Linnaeus, 1758) & NE, NY & Belton, 1984 \\
\hline Podicephorus major (Boddaert, 1783) & DY & Belton, 1984 \\
\hline Ciconia maguari (Gmelin, 1789) & NE, NY & Belton, 1984 \\
\hline Phalacrocorax brasilianus (Gmelin, 1789) & $\mathrm{NE}$ & This study \\
\hline Anhinga anhinga (Linnaeus, 1766) & NY & This study \\
\hline Tigrisoma lineatum (Boddaert, 1783) & $\mathrm{NE}$ & This study \\
\hline Botaurus pinnatus (Wagler, 1829) & NY & This study \\
\hline Ixobrychus involucris (Vieillot, 1823) & NY & Belton, 1984 \\
\hline Nycticorax nycticorax (Linnaeus, 1758) & NE, NY & Belton, 1984 \\
\hline Nyctanassa violacea (Linnaeus, 1758) & NE, NY & GIANUCA, 2007 \\
\hline Butorides striata (Linnaeus, 1758) & NY & Belton, 1984 \\
\hline Bubulcus ibis (Linnaeus, 1758) & $\mathrm{NE}, \mathrm{NY}$ & Belton, 1984 \\
\hline Ardea cocoi Linnaeus, 1766 & NY & Belton, 1984 \\
\hline Ardea alba Linnaeus, 1758 & $\mathrm{NE}, \mathrm{NY}$ & BeLton, 1984 \\
\hline
\end{tabular}


Appendix 1. Continue.

\begin{tabular}{|c|c|c|}
\hline Taxon & Breeding evidence & Source \\
\hline Syrigma sibilatrix (Temminck, 1824) & NY & BELton, 1984 \\
\hline Egretta thula (Molina, 1782) & NE, NY & BeLton, 1984 \\
\hline Egretta caerulea (Linnaeus, 1758) & NE, NY & GIANUCA et al., 2012 \\
\hline Plegadis chihi (Vieillot, 1817) & NE, NY & Belton, 1984 \\
\hline Mesembrinibis cayennensis (Gmelin, 1789) & DY & This study \\
\hline Phimosus infuscatus (Lichtenstein, 1823) & NE, NY & Belton, 1984 \\
\hline Theristicus caerulescens (Vieillot, 1817) & NY & This study \\
\hline Theristicus caudatus (Boddaert, 1783) & NY & Belton, 1984 \\
\hline Platalea ajaja Linnaeus, 1758 & NE, NY & Belton, 1984 \\
\hline Cathartes aura (Linnaeus, 1758) & NE, NY & This study \\
\hline Coragyps atratus (Bechstein, 1793) & NY & This study \\
\hline Chondrohierax uncinatus (Temminck, 1822) & DY & KRÜGEL, 2003 \\
\hline Elanus leucurus (Vieillot, 1818) & $\mathrm{NE}$ & Belton, 1984 \\
\hline Circus cinereus Vieillot, 1816 & NE, NY & BENCKE et al., 2003 \\
\hline Circus buffoni (Gmelin, 1788) & $\mathrm{NE}$ & САмiLOTTI et al., 2008 \\
\hline Ictinia plumbea (Gmelin, 1788) & NY & BELTON, 1984 \\
\hline Rostrhamus sociabilis (Vieillot, 1817) & DY & Belton, 1984 \\
\hline Heterospizias meridionalis (Latham, 1790) & NY & This study \\
\hline Geranoaetus albicaudatus Vieillot, 1816 & NY & This study \\
\hline Spizaetus ornatus (Daudin, 1800) & NY & JoENCK et al. (in press) \\
\hline Caracara plancus (Miller, 1777) & NY & This study \\
\hline Milvago chimango (Vieillot, 1816) & $\mathrm{NE}$ & This study \\
\hline Micrastur semitorquatus (Vieillot, 1817) & NE, NY & MARREIS et al., 2009 \\
\hline Falco sparverius Linnaeus, 1758 & NY & This study \\
\hline Aramus guarauna (Linnaeus, 1766) & DY & BeLton, 1984 \\
\hline Aramides ypecaha (Vieillot, 1819) & NE, DY & This study \\
\hline Aramides cajanea (Statius Muller, 1776) & DY & This study \\
\hline Aramides saracura $($ Spix, 1825$)$ & $\mathrm{NE}$ & Belton, 1984 \\
\hline Laterallus melanophaius (Vieillot, 1819) & DY & This study \\
\hline Laterallus leucopyrrhus (Vieillot, 1819) & $\mathrm{NE}$ & This study \\
\hline Pardirallus maculatus (Boddaert, 1783) & DY & MaURício \& Dias, 1996 \\
\hline Pardirallus sanguinolentus (Swainson, 1837) & DY & This study \\
\hline Gallinula galeata (Lichtenstein,1818) & DY & BeLton, 1984 \\
\hline Gallinula melanops (Vieillot, 1819) & DY & Belton, 1984 \\
\hline Porphyrio martinica (Linnaeus, 1766) & DY & Belton, 1984 \\
\hline Fulica armillata Vieillot, 1817 & NE, DY & Belton, 1984 \\
\hline Fulica rufifrons Philippi \& Landbeck, 1861 & NE, DY & This study \\
\hline Fulica leucoptera Vieillot, 1817 & NE, DY & BeLton, 1984 \\
\hline Cariama cristata (Linnaeus, 1766) & DY & Belton, 1984 \\
\hline Vanellus chilensis (Molina, 1782) & NE, NY & Belton, 1984 \\
\hline Charadrius collaris Vieillot, 1818 & $\mathrm{NE}$ & Belton, 1984 \\
\hline Charadrius falklandicus Latham, 1790 & DY & Belton, 1994 \\
\hline Haematopus palliatus Temminck, 1820 & DY & BELTON, 1984 \\
\hline Himantopus melanurus Vieillot, 1817 & DY & BeLton, 1984 \\
\hline Gallinago paraguaiae (Vieillot, 1816) & NE, DY & This study \\
\hline Gallinago undulata (Boddaert, 1783) & $\mathrm{NE}$ & REPENNING et al., 2010 \\
\hline Jacana jacana (Linnaeus, 1766) & NE, DY & Belton, 1984 \\
\hline Nycticryphes semicollaris (Vieillot, 1816) & $\mathrm{NE}$ & MaURício \& Dias, 1996 \\
\hline Chroicocephalus maculipennis (Lichtenstein, 1823) & NE, NY & This study \\
\hline Chroicocephalus cirrocephalus (Vieillot, 1818) & $\mathrm{NE}$ & This study \\
\hline Sternula superciliaris (Vieillot, 1819) & $\mathrm{NE}$ & BeLton, 1984 \\
\hline Phaetusa simplex (Gmelin, 1789) & NE, NY & EFE et al., 2001 \\
\hline Gelochelidon nilotica (Gmelin, 1789) & $\mathrm{NE}$ & This study \\
\hline Sterna trudeaui Audubon, 1838 & NE, NY & This study \\
\hline Rynchops niger Linnaeus, 1758 & NE, NY & EFE et al., 2001 \\
\hline Columbina talpacoti (Temminck, 1811) & NE, NY & BELTON, 1984 \\
\hline Columbina picui (Temminck, 1813) & $\mathrm{NE}$ & BELton, 1984 \\
\hline Columba livia Gmelin, 1789 & NY & This study \\
\hline
\end{tabular}


Appendix 1. Continue.

\begin{tabular}{|c|c|c|}
\hline Taxon & Breeding evidence & Source \\
\hline Patagioenas picazuro (Temminck, 1813) & NE, NY & BeLton, 1984 \\
\hline Patagioenas maculosa (Temminck, 1813) & NE, NY & BeLton, 1984 \\
\hline Zenaida auriculata (Des Murs, 1847) & $\mathrm{NE}$ & BeLton, 1984 \\
\hline Leptotila verreauxi Bonaparte, 1855 & NE, NY & Belton, 1984 \\
\hline Leptotila rufaxilla (Richard \& Bernard, 1792) & $\mathrm{NE}$ & This study \\
\hline Geotrygon montana (Linnaeus, 1758) & $\mathrm{NE}$ & MaURício \& Dias, 1998 \\
\hline Pyrrhura frontalis (Vieillot, 1817) & NE, NY & Belton, 1984 \\
\hline Myiopsitta monachus (Boddaert, 1783) & NY & This study \\
\hline Amazona vinacea (Kuhl, 1820) & $\mathrm{NE}$ & BeLton, 1984 \\
\hline Amazona pretrei (Temminck, 1830) & NE, NY & Belton, 1984 \\
\hline Triclaria malachitacea (Spix, 1824) & NY & BENCKE, 1998 \\
\hline Piaya cayana (Linnaeus, 1766) & NY & BeLton, 1984 \\
\hline Coccyzus melacoryphus Vieillot, 1817 & $\mathrm{NE}$ & Belton, 1984 \\
\hline Crotophaga ani Linnaeus, 1758 & NY & BeLton, 1984 \\
\hline Guira guira (Gmelin, 1788) & NY & BELtON, 1984 \\
\hline Tyto alba (Scopoli, 1769) & DY & BeLton, 1984 \\
\hline Megascops choliba (Vieillot, 1817) & DY & This study \\
\hline Bubo virginianus (Gmelin, 1788) & NY & Tomazzoni et al., 2004 \\
\hline Athene cunicularia (Molina, 1782) & NY & This study \\
\hline Asio clamator (Vieillot, 1808) & NY & OLIVEIRA, 1980 \\
\hline Asio stygius (Wagler, 1832) & NY & BELton, 1984 \\
\hline Nyctibius griseus (Gmelin, 1789) & DY & This study \\
\hline Antrostomus rufus (Boddaert, 1783) & $\mathrm{NE}$ & This study \\
\hline Antrostomus sericocaudatus Cassin, 1849 & NY & BENCKE et al., 2003 \\
\hline Hydropsalis albicollis (Gmelin, 1789) & NY & This study \\
\hline Hydropsalis parvula (Gould, 1837) & $\mathrm{NE}$ & Belton, 1984 \\
\hline Hydropsalis longirostris Bonaparte, 1825 & NE, DY & This study \\
\hline Hydropsalis torquata (Gmelin, 1789) & NE, NY & BELton, 1984 \\
\hline Chordeiles nacunda (Vieillot, 1817) & NY & Belton, 1984 \\
\hline Cypseloides fumigatus (Streubel, 1848) & NE, NY & This study \\
\hline Cypseloides senex (Temminck, 1826) & $\mathrm{NE}$ & OLIVEIRA, 2011 \\
\hline Streptoprocne zonaris (Shaw, 1796) & $\mathrm{NE}$ & This study \\
\hline Chaetura cinereiventris Sclater, 1862 & NY & This study \\
\hline Chaetura meridionalis Hellmayr, 1907 & NY & Belton, 1984 \\
\hline Phaethornis eurynome (Lesson, 1832) & NY & This study \\
\hline Thalurania glaucopis (Gmelin, 1788) & NE, NY & This study \\
\hline Hylocharis chrysura (Shaw, 1812) & $\mathrm{NE}$ & Belton, 1984 \\
\hline Leucochloris albicollis (Vieillot, 1818) & NE, NY & Belton, 1984 \\
\hline Polytmus guainumbi (Pallas, 1764) & $\mathrm{NE}$ & This study \\
\hline Amazilia fimbriata (Gmelin, 1788) & DY & This study \\
\hline Heliomaster furcifer (Shaw, 1812) & DY & This study \\
\hline Trogon surrucura Vieillot, 1817 & NE, NY & Belton, 1984 \\
\hline Chloroceryle amazona (Latham, 1790) & NY & Belton, 1984 \\
\hline Chloroceryle americana (Gmelin, 1788) & NY & Belton, 1984 \\
\hline Nystalus chacuru (Vieillot, 1816) & DY & This study \\
\hline Ramphastos toco Statius Muller, 1776 & NY & This study \\
\hline Ramphastos dicolorus Linnaeus, 1766 & NY & MaURício \& Dias, 1998 \\
\hline Picumnus temminckii Lafresnaye, 1845 & NY & This study \\
\hline Picumnus nebulosus Sundevall, 1866 & NY & This study \\
\hline Veniliornis spilogaster (Wagler, 1827) & NY & This study \\
\hline Colaptes melanochloros (Gmelin, 1788) & NY & This study \\
\hline Colaptes campestris (Vieillot, 1818) & NY & Belton, 1984 \\
\hline Dryocopus lineatus (Linnaeus, 1766) & NY & Maurício \& Dias, 1998 \\
\hline Campephilus robustus (Lichtenstein, 1818) & NY & This study \\
\hline Myrmeciza squamosa Pelzeln, 1868 & DY & This study \\
\hline Dysithamnus mentalis (Temminck, 1823) & $\mathrm{NE}$ & This study \\
\hline Thamnophilus ruficapillus Vieillot, 1816 & DY & Belton, 1994 \\
\hline Thamnophilus caerulescens Vieillot, 1816 & $\mathrm{NE}$ & Belton, 1985 \\
\hline
\end{tabular}


Appendix 1. Continue.

\begin{tabular}{|c|c|c|}
\hline Taxon & Breeding evidence & Source \\
\hline Conopophaga lineata (Wied, 1831) & NE, NY & This study \\
\hline Scytalopus speluncae (Ménétriés, 1835) & NY & This study \\
\hline Chamaeza campanisona (Lichtenstein, 1823) & $\mathrm{NE} / \mathrm{NY}$ & Franz (in press) \\
\hline Lepidocolaptes angustirostris (Vieillot, 1818) & NY & BeLton, 1984 \\
\hline Dendrocolaptes platyrostris Spix, 1825 & NY & This study \\
\hline Cinclodes pabsti Sick, 1969 & NY & BeLton, 1984 \\
\hline Furnarius rufus (Gmelin, 1788) & NY & BeLton, 1984 \\
\hline Limnornis curvirostris Gould, 1839 & $\mathrm{NE}$ & This study \\
\hline Phleocryptes melanops (Vieillot, 1817) & $\mathrm{NE}$ & Belton, 1984 \\
\hline Syndactyla rufosuperciliata (Lafresnaye, 1832) & NY & Belton, 1984 \\
\hline Leptasthenura platensis Reichenbach, 1853 & NY & Belton, 1984 \\
\hline Leptasthenura striolata (Pelzeln, 1856) & NY & Belton, 1984 \\
\hline Spartonoica maluroides (d'Orbigny \& Lafresnaye, 1837) & NY & DiAs et al., 2009 \\
\hline Pseudoseisura lophotes (Reichenbach, 1853) & NY & This study \\
\hline Phacellodomus striaticollis (d'Orbigny \& Lafresnaye, 1838) & NE, NY & This study \\
\hline Anumbius annumbi (Vieillot, 1817) & NY & This study \\
\hline Certhiaxis cinnamomeus (Gmelin, 1788) & $\mathrm{NE}$ & BeLton, 1984 \\
\hline Synallaxis cinerascens Temminck, 1823 & DY & This study \\
\hline Limnoctites rectirostris (Gould, 1839) & NE, NY & REPENNING et al., 2010 \\
\hline Cranioleuca pyrrhophia (Vieillot, 1818) & NY & BeLton, 1984 \\
\hline Cranioleuca obsoleta (Reichenbach, 1853) & $\mathrm{NE}$ & This study \\
\hline Chiroxiphia caudata (Shaw \& Nodder, 1793) & NE, NY & This study \\
\hline Tityra inquisitor (Lichtenstein, 1823) & DY & This study \\
\hline Carpornis cucullata (Swainson, 1821) & NE, NY & This study \\
\hline Phibalura flavirostris Vieillot, 1816 & NY & Belton, 1985 \\
\hline Tachuris rubrigastra (Vieillot, 1817) & NE, NY & This study \\
\hline Mionectes rufiventris Cabanis, 1846 & $\mathrm{NE}$ & BENCKE, 1995 \\
\hline Leptopogon amaurocephalus Tschudi, 1846 & NY & This study \\
\hline Phylloscartes ventralis (Temminck, 1824) & NE, NY & Belton, 1985 \\
\hline Tolmomyias sulphurescens (Spix, 1825) & NE, NY & This study \\
\hline Poecilotriccus plumbeiceps (Lafresnaye, 1846) & NE, NY & This study \\
\hline Hemitriccus obsoletus (Miranda-Ribeiro, 1906) & $\mathrm{NE}$ & BENCKE et al., 2001 \\
\hline Hirundinea ferruginea (Gmelin, 1788) & NY & This study \\
\hline Euscarthmus meloryphus Wied, 1831 & $\mathrm{NE}$ & This study \\
\hline Camptostoma obsoletum (Temminck, 1824) & NY & BeLton, 1985 \\
\hline Elaenia flavogaster (Thunberg, 1822) & DY & This study \\
\hline Elaenia spectabilis Pelzeln, 1868 & NE, NY & HOFFMANN \& KRÜGEL, 2007 \\
\hline Elaenia parvirostris Pelzeln, 1868 & $\mathrm{NE}$ & BeLton, 1985 \\
\hline Elaenia mesoleuca (Deppe, 1830) & NY & BeLton, 1985 \\
\hline Elaenia obscura (d'Orbigny \& Lafresnaye, 1837) & $\mathrm{NE}$ & This study \\
\hline Phyllomyias fasciatus (Thunberg, 1822) & $\mathrm{NE}$ & BeLton, 1985 \\
\hline Culicivora caudacuta (Vieillot, 1818) & NY & REPENNING et al., 2010 \\
\hline Serpophaga nigricans (Vieillot, 1817) & $\mathrm{NE}$ & Belton, 1985 \\
\hline Serpophaga subcristata (Vieillot, 1817) & NY & Belton, 1985 \\
\hline Myiarchus swainsoni Cabanis \& Heine, 1859 & NY & Belton, 1985 \\
\hline Pitangus sulphuratus (Linnaeus, 1766) & NY & Belton, 1985 \\
\hline Machetornis rixosa (Vieillot, 1819) & NY & Belton, 1985 \\
\hline Myiodynastes maculatus (Statius Muller, 1776) & NY & This study \\
\hline Tyrannus melancholicus Vieillot, 1819 & DY & BeLton, 1985 \\
\hline Tyrannus savana Vieillot, 1808 & NE, NY & BeLton, 1985 \\
\hline Empidonomus varius (Vieillot, 1818) & NE, NY & This study \\
\hline Myiophobus fasciatus (Statius Muller, 1776) & $\mathrm{NE}$ & BeLton, 1985 \\
\hline Sublegatus modestus (Wied, 1831) & NY & BeLton, 1985 \\
\hline Pyrocephalus rubinus (Boddaert, 1783) & NY & This study \\
\hline Cnemotriccus fuscatus (Wied, 1831) & NY & BeLton, 1985 \\
\hline Lathrotriccus euleri (Cabanis, 1868) & NE, NY & This study \\
\hline Knipolegus lophotes Boie, 1828 & $\mathrm{NE}$ & BeLton, 1985 \\
\hline Hymenops perspicillatus (Gmelin, 1789) & NE, NY & This study \\
\hline
\end{tabular}


Appendix 1. Continue.

\begin{tabular}{|c|c|c|}
\hline Taxon & Breeding evidence & Source \\
\hline Satrapa icterophrys (Vieillot, 1818) & NE, NY & This study \\
\hline Xolmis cinereus (Vieillot, 1816) & NE, NY & BELTON, 1985 \\
\hline Xolmis irupero (Vieillot, 1823) & NY & Belton, 1985 \\
\hline Xolmis dominicanus (Vieillot, 1823) & $\mathrm{NE}$ & FontANA, 1998 \\
\hline Muscipipra vetula (Lichtenstein, 1823) & $\mathrm{NE}$ & FONTANA et al., 2000 \\
\hline Vireo olivaceus (Linnaeus, 1766) & $\mathrm{NE}$ & This study \\
\hline Pygochelidon cyanoleuca (Vieillot, 1817) & NY & Belton, 1985 \\
\hline Alopochelidon fucata (Temminck, 1822) & NY & Belton, 1985 \\
\hline Stelgidopteryx ruficollis (Vieillot, 1817) & NY & This study \\
\hline Progne tapera (Vieillot, 1817) & NY & Belton, 1985 \\
\hline Progne chalybea (Gmelin, 1789) & NY & BeLton, 1985 \\
\hline Tachycineta leucorrhoa (Vieillot, 1817) & NY & BeLton, 1985 \\
\hline Troglodytes musculus Naumann, 1823 & NY & Belton, 1985 \\
\hline Polioptila dumicola (Vieillot, 1817) & NE, NY & BeLton, 1985 \\
\hline Turdus flavipes Vieillot, 1818 & DY & This study \\
\hline Turdus rufiventris Vieillot, 1818 & NE, NY & BeLton, 1985 \\
\hline Turdus leucomelas Vieillot, 1818 & NY & BeLton, 1985 \\
\hline Turdus amaurochalinus Cabanis, 1850 & NE, NY & BeLton, 1985 \\
\hline Turdus subalaris (Seebohm, 1887) & $\mathrm{NE}$ & Belton, 1985 \\
\hline Turdus albicollis Vieillot, 1818 & NY & Belton, 1985 \\
\hline Mimus saturninus (Lichtenstein, 1823) & NE, NY & Belton, 1985 \\
\hline Anthus lutescens Pucheran, 1855 & $\mathrm{NE}$ & This study \\
\hline Anthus furcatus d'Orbigny \& Lafresnaye, 1837 & NY & Belton, 1985 \\
\hline Anthus correndera Vieillot, 1818 & NE, NY & This study \\
\hline Anthus hellmayri Hartert, 1909 & $\mathrm{NE}$ & This study \\
\hline Coereba flaveola (Linnaeus, 1758) & NE, NY & This study \\
\hline Saltator similis d'Orbigny \& Lafresnaye, 1837 & $\mathrm{NE}$ & This study \\
\hline Saltator aurantiirostris Vieillot, 1817 & $\mathrm{NE}$ & This study \\
\hline Tachyphonus coronatus (Vieillot, 1822) & DY & This study \\
\hline Lanio cucullatus (Statius Muller, 1776) & NY & This study \\
\hline Lanio melanops (Vieillot, 1818) & DY & This study \\
\hline Tangara seledon (Statius Muller, 1776) & $\mathrm{NE}$ & This study \\
\hline Tangara sayaca (Linnaeus, 1766) & NE, NY & Belton, 1985 \\
\hline Stephanophorus diadematus (Temminck, 1823) & DY & This study \\
\hline Paroaria coronata (Miller, 1776) & NY, DY & This study \\
\hline Paroaria capitata (d'Orbigny \& Lafresnaye, 1837) & NE & This study \\
\hline Pipraeidea melanonota (Vieillot, 1819) & NY & Belton, 1985 \\
\hline Pipraeidea bonariensis (Gmelin, 1789) & NY & BeLton, 1985 \\
\hline Zonotrichia capensis (Statius Muller, 1776) & $\mathrm{NE}$ & Belton, 1985 \\
\hline Ammodramus humeralis (Bosc, 1792) & NE, NY & Belton, 1985 \\
\hline Haplospiza unicolor Cabanis, 1851 & DY & This study \\
\hline Donacospiza albifrons (Vieillot, 1817) & NE, NY & This study \\
\hline Poospiza nigrorufa (d'Orbigny \& Lafresnaye, 1837) & $\mathrm{NE}$ & This study \\
\hline Poospiza cabanisi Bonaparte, 1850 & $\mathrm{NE}$ & This study \\
\hline Poospiza melanoleuca (d’Orbigny \& Lafresnaye, 1837) & DY & This study \\
\hline Sicalis flaveola (Linnaeus, 1766) & $\mathrm{NE}$ & Belton, 1985 \\
\hline Sicalis luteola (Sparrman, 1789) & NE, NY & Belton, 1985 \\
\hline Emberizoides herbicola (Vieillot, 1817) & $\mathrm{NE}$ & This study \\
\hline Emberizoides ypiranganus Ihering \& Ihering, 1907 & NE & This study \\
\hline Embernagra platensis (Gmelin, 1789) & NE, NY & This study \\
\hline Sporophila collaris (Boddaert, 1783) & $\mathrm{NE}$ & BENCKE et al., 2003 \\
\hline Sporophila lineola (Linnaeus, 1758) & NY & This study \\
\hline Sporophila caerulescens (Vieillot, 1823) & NE, NY & Belton, 1985 \\
\hline Sporophila bouvreuil (Statius Muller, 1776) & DY & This study \\
\hline Sporophila palustris (Barrows, 1883) & NE, NY, DY & This study \\
\hline Sporophila cinnamomea (Lafresnaye, 1839) & NY & This study \\
\hline Sporophila melanogaster (Pelzeln, 1870) & $\mathrm{NE}$ & RovedDer \& Fontana, 2012 \\
\hline Habia rubica (Vieillot, 1817) & $\mathrm{NE}$ & This study \\
\hline
\end{tabular}


Appendix 1. Continue.

\begin{tabular}{lcc}
\hline Taxon & Breeding evidence & Source \\
\hline Cyanoloxia glaucocaerulea (d'Orbigny \& Lafresnaye, 1837) & NE & This study \\
Geothlypis aequinoctialis (Gmelin, 1789) & NE, NY & This study \\
Basileuterus culicivorus (Deppe, 1830) & DY & BELTON, 1985 \\
Basileuterus leucoblepharus (Vieillot, 1817) & NE & BELTON, 1985 \\
Cacicus chrysopterus (Vigors, 1825) & NY & This study \\
Cacicus haemorrhous (Linnaeus, 1766) & NY & This study \\
Icterus pyrrhopterus (Vieillot, 1819) & NE, NY & This study \\
Chrysomus ruficapillus (Vieillot, 1819) & NE & BELTON, 1985 \\
Xanthopsar flavus (Gmelin, 1788) & NE, NY & BELTON, 1985 \\
Pseudoleistes guirahuro (Vieillot, 1819) & NE & This study \\
Agelaioides badius (Vieillot, 1819) & NY & BELTON, 1985 \\
Molothrus bonariensis (Gmelin, 1789) & NE & BELTON, 1985 \\
Sturnella superciliaris (Bonaparte, 1850) & NE & This study \\
Euphonia chlorotica (Linnaeus, 1766) & NE, NY & This study \\
Euphonia cyanocephala (Vieillot, 1818) & NY & BELTON, 1985 \\
Chlorophonia cyanea (Thunberg, 1822) & NE & This study \\
Passer domesticus (Linnaeus, 1758) & NY & This study \\
\hline
\end{tabular}

Received 19 February 2013. Accepted 3 June 2013. ISSN 0073-4721

Article available at: www.scielo.br/isz 